This chapter investigates some of the motives of the Danish nobles who visited Jerusalem after the Reformation roughly in the period 1555-1650. It will demonstrate how several elements of the medieval crusade continued as part of the royal and national ideology, as well as part of the ideals and religious life of Protestant knighthood. It analyses the travel accounts, crusade literature, knightly orders, and expressions of national crusading ideology, which form an important background and context for understanding the continued travels of the nobility to Jerusalem.

In 1684 the Danish statesman and jurist Peder Hansen Resen (1625-88) published Erik Krabbe's (1510-64) sixteenth-century German translation of the old Danish lawcollection Law of Jutland from the thirteenth century. In the preface he wrote about various subjects. Among others, he described how his brother, Dr Poul Resen (d. 1657), went on a journey to Constantinople and the Holy Sepulchre in Jerusalem. When he reached the Franciscan monastery on Mount Zion, he was very well received and the monks played music for him. They believed him to be fond of music because he carried a fiddle with him. In the evening, when Poul Resen went to bed, he was placed in a room on the door of which was carved four letters and then "Ottho Schram Danus 1599.” Poul Resen had promised to write more of this when he reached Cairo, but unfortunately, he died on the way from the Holy Sepulchre to Cairo in 1657.

A certain Otto Skram had in fact visited Jerusalem in the 1590s. He travelled in the company of three companions from Constantinople as "pilgrims" to Jerusalem after several years in imperial service in Europe. According to his detailed travel account, he visited the holy places and was even knighted at the Holy Sepulchre before returning to Denmark. Otto Skram and Poul Resen were but two of several Danish nobles who visited Jerusalem towards the end of the sixteenth and in the early seventeenth century bearing witness to a continued interest in the Holy City among Protestant nobles.

It has often been argued by both contemporaries and modern historians that they undertook these journeys more for the sake of learning about other cultures than for the sake of religion. Generally speaking, however, the travel accounts of Danish nobles of the sixteenth century did not differ substantially from those of

Janus Møller Jensen, Director, The Danish Jewish Museum, Copenhagen, Denmark 


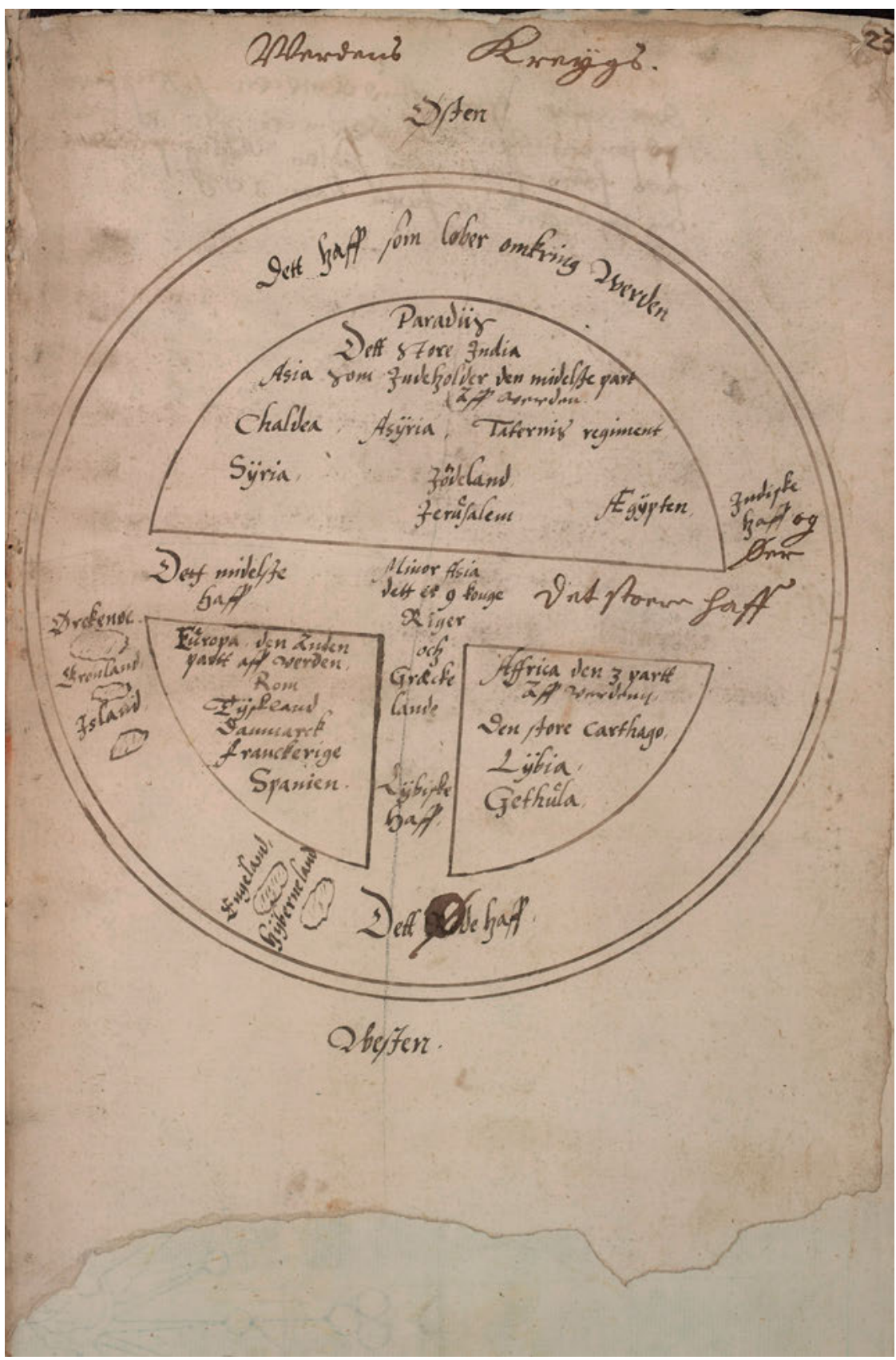

Fig. 11.1: T-O map drawn by the Danish theologian and historian Christiern Pedersen in 1521. Several copies exist. This is probably the oldest, dated around 1550 . From ms. Thott 79720 , fol. 277. (Det Kongelige Bibliotek). Jerusalem and "Jødeland” (“Land of the Jews") is still central to conception of the world. 
their Catholic peers, and the sense of awe at being near the holiest places was genuinely expressed. In general, the pilgrimage elements in the Catholic sense, if not disappearing completely, naturally waned after the Reformation, but as the scene for the passion of Christ Jerusalem of course remained a place of central importance within the Protestant faith. Further, Protestant nobles continued to be knighted at the Holy Sepulchre and there was an outspoken and deliberate identification of being knighted at the Holy Sepulchre with the crusading pre-Reformation past that has not received much attention in modern research. The purpose of the present chapter will be to investigate some of the motives of the Danish nobles who visited Jerusalem after the Reformation roughly in the period 1550-1650. It will demonstrate how several elements of the medieval crusade continued long after the Reformation ostensibly should have put an end to its existence. These elements were parts of the royal and national ideology as well as the ideals and religious life of Protestant knighthood. They hence formed an important background for understanding the travels of the nobility to Jerusalem.

\section{Brief Historiography}

The first to write about the journeys to Jerusalem in the sixteenth and seventeenth centuries were the people who actually went there. Several travel accounts from nobles visiting the Holy Sepulchre have been preserved. ${ }^{1}$ They describe in detail the journey itself and what they experienced once they reached Jerusalem. In some of these accounts, the visit to Jerusalem and the Holy Land only formed part of longer journeys, which for instance included visits to Syria and Egypt. Even if some of them describe in detail the visits to all of the scenes of Christ's passion and biblical history in Jerusalem and the Holy Land that indicates both an emotional and religious experience like in Catholic times, they are sparse on actual information concerning the personal motives of the travellers. The journeys are sometimes mentioned and briefly described in contemporary eulogies. In these sources, the motives of those who went to Jerusalem are often described in the context of the official Lutheran-Evangelical confession. The authors often focus on the educational purposes of the journeys and the need to gain knowledge of other cultures to be put to use for the fatherland. Some of the travel-accounts were published as early as the seventeenth century. ${ }^{2}$ Several of the Danish eulogies were printed in their own day too, but published as sources for the history of the nobility and their work on behalf of the fatherland in

\footnotetext{
1 Cf. below.

2 The first eulogy to be printed in Denmark dates from 1565, cf. Grethe Jacobsen, "Danske ligprædikener 1565-1610. Køn, stand og embede i en litterær genre,” Historisk Tidsskrift 115, no. 2 (2015).
} 
the middle of the eighteenth century. ${ }^{3}$ At the same time, there appeared an academic interest in these journeys. In 1740-41, the Danish theologian, historian, antiquarian and - for a period - bishop of Bergen in western Norway, Erik Pontoppidan (1698-1764), published his Gesta et Vestigia Danorum extra Daniam in three volumes. It is basically a compilation of sources and secondary works bearing upon the deeds of the Danes and Norwegians all over the world throughout recorded history. The first chapter deals with Danes in the Orient, divided into three groups: pilgrims, who went for religious purposes, ${ }^{4}$ warriors and crusaders, ${ }^{5}$ and those who went for various other purposes. ${ }^{6}$ This third group included some travellers in the sixteenth and seventeenth centuries. The purposes and motives identified by Pontoppidan included lust for travel [curiositatem peregrinandi], the study of language, marriage, trade, or simply the result of being exiled or as refugees. ${ }^{7}$ As an example of the first category, the journey of Otto Skram was mentioned in some detail. Pontoppidan remarks that no one else besides the noble Henrik Rantzau (1599-1674) appeared to have visited the Holy Sepulchre out of "curious superstition" after Skram, which of course is not true. The work was a huge antiquarian compilation and achievement, but it was not very critical.

In his work on the pilgrimages of the Northern peoples to "Greece", which included the Holy Land, published in 1758 the Swedish linguist and professor at Uppsala University Johan Ihre (1707-80) added the Swedes to the picture and included the runic inscriptions as sources. ${ }^{8}$ In 1813 , the Danish antiquarian and historian Lauritz Schebye Vedel Simonsen (1780-1858) published a study on Danish participation in the crusades and pilgrimages to the Holy Land, and he continued his investigation to include Danish pilgrims to the Holy Land in the fourteenth, fifteenth, sixteenth, and seventeenth centuries. ${ }^{9}$ This inspired the Swedish historian Ebbe Samuel Bring to publish a similar work in 1827, which focused on the Swedish participation in the

3 Casper Peter Rothe, Brave danske Mænds og Qvinders berømmelige Eftermæle, 2 vols. (Copenhagen, 1753).

4 Erich Pontoppidan, Gesta et vestigia Danorum (Leipzig: Jacob Preuss, 1740-41), 1:5-20.

5 Pontoppidan, Gesta et vestigia Danorum, 1:20-55.

6 Pontoppidan, Gesta et vestigia Danorum, 1:55-75.

7 The work of Pontoppidan is dedicated to the crown-prince whose love of history, Pontoppidan hoped, may be even more firmly strengthened by reading about the glorious deeds of his subjects, and the work is born from a warm and strong national sentiment. Cf. Michael Neiiendam, Erik Pontoppidan. Studier og bidrag til pietismens historie, 2 vols (Copenhagen: Gad, 1930-33), 2:114-16.

8 Johan Ihre, Disputatio academica, sistens peregrinationes gentium septentrionalium in græciam (Uppsala: L. M. Höjer, 1758).

9 Laurits Schebye Vedel Simonsen, "Historisk udsigt over nordiske valfarter og korstog til det hellige land," in Udsigt over nationalhistoriens ældste og mærkligste perioder. Vol. 2/2 (Copenhagen, 1813), 3, 151-77. Lauritz Schebye Vedel Simonsen's work is antiquarian in its scope and not free of some medieval romanticism, but it is nevertheless a huge achievement and the obvious starting point for any investigation of crusading history in Denmark. For a more general evaluation of Vedel Simonsen and his work, cf. Niels Henrik Holmqvist-Larsen, “'Sagas yndede og trofast hengivne Søn’ - Om Lauritz Schebye Vedel 
crusades to the Holy Land. He too included pilgrims from 1291 to the sixteenth century although the reference was very brief and merely consisted of a list of names. ${ }^{10}$ Vedel Simonsen clearly believed that the journeys to the Orient of the Danish nobility in the sixteenth and seventeenth centuries were a direct continuation of the medieval pilgrimage to Jerusalem that gradually developed into the scientific journeys of a later age. Henny Glarbo came to the directly opposite conclusion in her article on Danish travellers to Jerusalem from $1936 .{ }^{11}$ She stated that it was no longer possible to identify the motives of the travellers but concluded that it appeared as if religious and scientific motives only occasionally had been predominant. According to Glarbo, the men of the Reformation area experienced a communal dread for anything Catholic including pilgrimages, but towards the end of the sixteenth century, when travels had become part of the education of young noblemen, several undertook the journey to the Orient. They did this, however, in order to be acquainted with foreign cultures and they returned with more knowledge, a wider horizon, and wiser as part of their education rather than for reasons associated with the pilgrimage tradition. This appears to be accepted by Benedikt Otzen who, besides providing interesting new material concerning the known journeys of the nobility, thinks that the Protestant accounts both expressed sincere curiosity about foreign cultures and voiced the Protestant scepticism when confronted with the many biblical legends. ${ }^{12}$ This has become the predominant view in more recent studies of the educational journeys of the Danish nobility in the sixteenth and seventeenth centuries. ${ }^{13}$

The historians and antiquarians of the eighteenth and early nineteenth century thus clearly understood the journeys of the nobility to Jerusalem in sixteenth- and seventeenth-century Denmark as rooted in the crusading past and to them the continuity was obvious. Only in the case of the succeeding centuries did the travels turn into something else. Later studies, forming the predominant view today, instead saw a clear break with the Reformation and viewed the journeys to the Orient

Simonsen til Elvedgård, 1780-1858," in Fynske Antikvarer. Lærdom, fortid og fortolkninger, 1550-1850, edited by Janus Møller Jensen (Odense: Syddansk Universitetsforlag, 2008), 93-143.

10 Ebbe Samuel Bring, Om valfarterna och korstågen från Skandinavien till Heliga Landet: En historisk undersökning (Lund: Berlingska, 1827). The church historian and bishop of Copenhagen Friederich Münter (1761-1830) did treat Sweden briefly, although he cited no evidence for Swedish participation before the Third Crusade, Friederich Münter, "Allgemeine Bemerkungen über die Theilnahme der nordischen Völker an den Krezzügen, und deren Wirkungen auf die Kultur den Nordens,” in Vermischte Beyträge zur Kirchengeschichte (Copenhagen: Proft und Storch, 1798), 370-73.

11 Henny Glarbo, "Danske Palæstinafarere i det 16. og 17. Aarhundrede,” Kirkehistoriske Samlinger 6, no. 2 (1936-38): 1-32.

12 Benedikt Otzen, "Johan Rantzau og Andre Adelsmænd i Jerusalem," in Humanitet og eksistens en artikelsamling til Børge Diderichsen, ed. Knud Hansen, Svend Holm-Nielsen, and Bent Hahn (Copenhagen: Gyldendal, 1976), 65-80.

13 Cf. for example Vello Helk, Dansk-Norske studierejser fra reformationen til enevælden 1536-1660. Med en matrikel over studerende i udlandet (Odense: Odense Universitetsforlag, 1987). 
only as a part of the general trend of the nobility to undertake educational journeys motivated mostly by a lust for travel and to gain knowledge of other cultures. This should, however, be seen against a more general trend in which the Catholic travellers and their accounts also placed increased focus on other aspects than the pilgrimage proper. They describe ancient monuments, plants and animals, cities, and fortifications to an extent where they were criticized by contemporaries for not undertaking these journeys with the proper Christian intentions. ${ }^{14}$ Simultaneously, Protestant nobles did take an outspoken interest in holy sites and relics. ${ }^{15}$ There can be little doubt that pilgrimage in the Catholic sense were abandoned officially with the Reformation and that the travels undertaken in the sixteenth and seventeenth centuries did indeed form part of the education of the nobility. However, few Danish scholars appear to have noticed that these journeys coincide with a growing interest in crusading history as part of constructing a national history in which the Danish kings and nobles had a long tradition for fighting for the true faith. This forms another direct link to the pre-Reformation crusading past in which Jerusalem and the Holy Land hold a central position and importance. It suggests a continuity as seen in the older historiography and opens up for a new investigation of the travels from this perspective.

The continued appeal of crusading ideals on both sides of the confessional divide in sixteenth- and seventeenth-century Europe has been the subject of some study in modern crusade scholarship. In the seventeenth century, "the crusade was employed to support a sense of national identity or pride explicitly derived from the pre-Reformation past and deliberately non-confessional”, as Christopher Tyerman has written. ${ }^{16}$ Tyerman has also drawn attention to the fact that Protestant nobles continued to take part in the crusades in the sixteenth century from England. ${ }^{17}$ Norman Housley has pointed out how the Holy Land and Jerusalem became

14 Marianne P. Ritsema van Eck, "Encounters with the Levant: The Late Medieval Illustrated Jerusalem Travelogue by Paul Walter Von Guglingen,” Mediterranean Historical Review 32, no. 2 (2017b), 153-88; Nicole Chareyron, Pilgrims to Jerusalem in the Middle Ages (New York: Columbia University Press, 2005), 14-15.

15 Cf. also the travel diary of the noble and royal councilor Christen Skeel (1623-88), who exults in the many relics he encounters on his way through France. He visited, for example, Saint Denis several times in order to see all that was kept there. He later visited the Knights of Saint John on Malta and fought in their ranks against the Turks on a six-week naval expedition, Christen Skeels Resedagbok 1619-1627, ed. Lennart Tomner (Malmö: Allhem, 1961).

16 Christopher J. Tyerman, "Holy War, Roman Popes, and Christian Soldiers: Some Early Modern Views on Medieval Christendom,” in The Medieval Church: Universities, Heresy, and the Religious Life. Essays in Honour of Gordon Leff, eds. Peter Biller and Barrie Dobson, Studies in Church History, Subsidia 11 (Woodbridge: Boydell, 1999). Cf. Matthias Pohlig, "Konfessionskulturelle Deutungsmuster internationaler Konflikte um 1600 - Kreuzzug, Antichrist, tausendjähriges Reich,” Archiv für Reformationsgeschichte 93 (2002).

17 Christopher Tyerman, England and the Crusades, 1095-1588 (Chicago: University of Chicago Press, 1988). 
transplanted to the new national monarchies of the late medieval and renaissance Europe. He argues that rather than diminishing interest in the "real" Jerusalem this transfer helped keeping it alive. The role of the Holy Land as a Patria communis, however, declined towards the end of the sixteenth century and it simply became a destination for travellers. ${ }^{18}$ So far, the Danish travels have not been investigated from this perspective.

\section{Late Medieval Pilgrims to Jerusalem}

Crusading and pilgrimage to Jerusalem were an integral part of late medieval political, religious, and noble life. Although we do not have detailed travel accounts from the fifteenth century from Scandinavia, quite a number of named pilgrims to the Holy Land are known through the papal licenses allowing them to go. Several itineraries have been preserved, both the more common ones in Latin - like Burchard de Monte Sion's - and some in Danish. ${ }^{19}$ The journey of two Danish nobles Wulf and Benedikt Pogwisch to Jerusalem is known from a German travel account, ${ }^{20}$ and from

18 Norman Housley, "Holy Land or Holy Lands? Palestine and the Catholic West in the Late Middle Ages and Renaissance," Studies in Church History 36 (The Holy Land, Holy Lands, and Christian History) (2000).

19 A Danish fifteenth-century itinerary is found in ms. AM $7924^{\circ}$ edited in M. Lorenzen and John Mandeville, Mandevilles rejse: i gammeldansk oversættelse; tillige med en vejleder for pilgrimme, vol. 5, Recueil Des Voyages (København, 1882). An Itinerarium Hyerosolimitanum was found in the library of the Cistercian Monastery Øm [Cara Insula] when an inventory was made in 1554 at the request of the king, cf. Bo Gregersen, Carsten Selch Jensen, and Carsten Selch Jensen, Øm kloster: Kapitler af et middelalderligt cistercienserabbedis historie (Odense: Øm Kloster Museum; i kommission hos Syddansk Universitetsforlag, 2003), 226. Burchard de Monte Sion's is found in several manuscripts in Copenhagen and Uppsala. At least one was copied in Vadstena towards the end of the fourteenth century, UUB: C14, fols. 2r-17r. A Viagium Terrae Sanctae was copied in Vadstena in the fifteenth century, UUB: C43, fols. 18v-20v. The twelfth-century itinerary by Nikulás of Munkabverá in Icelandic was copied in Iceland in 1387, Kristian Kålund, Alfræði Íslenzk. Islandsk encyklopædisk litteratur. I. Cod. Mbr. Am. 194, 8o. (København: n.pub., 1908), 12-23; Janus Møller Jensen, “Christian IV og korstogene,” Siden Saxo 21 no. 1 (2004). Perhaps the version of Burchard de Monte Sion's Descriptio Terræ Sanctæ found in UUB: C14 was written in Sweden towards the end of the fourteenth century when it was in Vadstena Library. It is followed in the manuscript by a series of sermons "de pugna spirituali," cf. Margarete Andersson-Schmitt, Monica Hedlund, and Håkan Hallberg, Mittelalterliche Handschriften der Universitätsbibliothek Uppsala: Katalog über die C-Sammlung. Bd 7: Supplement, Hauptregister, Supplement, Hauptregister (Uppsala: Uppsala Universitet, 1988-95), 1:148-49.

20 They were identified by Michael Venge in his book Mikael Venge, Christian 2.s fald: Spillet om magten i Danmark januar-februar 1523, Odense University Studies in History and Social Sciences 6 (Odense: Odense University Press, 1972), 92, n. 54. from a German travel account from 1517 published in the middle of the nineteenth century, cf. Otzen, "Johan Rantzau og andre adelsmænd i Jerusalem," 73-76. 
the early sixteenth century, the Danish travel accounts begin to appear. In 1518, the two nobles Holger Gregersen Ulfstand (d. 1532) and Johan Oxe (d. 1534) went to Jerusalem, of which they left an account. ${ }^{21}$ Another early sixteenth-century account of a journey to Jerusalem is preserved in the same manuscripts. ${ }^{22}$ It was not uncommon that nobles went to Jerusalem shortly after having been involved in heavy fighting. One of King Hans's (1481-1513) admirals, Otte Rud (d. 1510) - who according to the chronicle of the reform-Catholic Paulus Helie (1485-1535) was one of the renowned leaders in the maritime war fought between King Hans and Sweden and Lübeck went to Jerusalem in 1509 but died on the way in the Bavarian town of Landsbjerg in 1510. Perhaps his pilgrimage is to be seen in connection with his exploits during the wars. In August 1509, he took the city of Åbo (Turku) in Finland with a Danish fleet. The succeeding sack of the city that lasted five days was even according to contemporary standards extraordinarily thorough and harsh. The cathedral of the city was especially plundered. ${ }^{23}$ When it comes to the pilgrimage of Johan Oxe in 1518, it has been suggested that it was undertaken for his guilt in the conviction and execution of his brother, Torben Oxe (d. 1517), but the travel account does not provide any evidence for the exact motives. ${ }^{24}$ The nobleman Mogens Gyldenstierne (1485-1569) was knighted by Christian II (1513-23) for his part in the conquest of Stockholm in 1520. Afterwards he went to Jerusalem where he was knighted at the Holy Sepulchre. Afterwards he bathed in the River Jordan "where our Lord, Jesus Christ was baptized". ${ }^{25}$ Perhaps he felt guilty for his part in the condemning and execution of a large number of Swedish nobles and ecclesiastics in the wake of the Danish victory and reincorporation of Sweden into the Kalmar Union, known as the bloodbath

21 KB: GkS $8442^{\circ}$, fols. 235v-39r. Another copy is preserved in KB: NkS $5402^{\circ}$, fols. 11 r-16r. It has been edited by Holger F. Rørdam, “Danskes rejser til det Hellige Land,” in Kirkehistoriske Samlinger 5, no. 1 (1901-03), 484-92.

22 KB: GkS 844 2 , fols. 240v-245v; KB: NkS $5402^{\circ}$, fols. 17v-21r. It has been edited by Rørdam, "Danskes rejser til det Hellige Land," 698-706, who dated it around 1500, but Benedikt Otzen has provided some compelling arguments for dating the journey it describes rather precisely to 1516, and thus the account immediately after, Otzen, "Johan Rantzau og andre adelsmænd i Jerusalem," 70-72. 23 Paulus Helie, Chronicon Skibyense, in Skrifter af Paulus Helie, ed. P. Severinsen, Marius Kristensen, Hans Ræder and Niels-Knud Andersen, 7 vols (Copenhagen: Gyldendalske Boghandel, 1932-48), 6:51-149, at 69-70; Henry Bruun, “Otto Rud,” in Dansk Biografisk Leksikon, ed. Sv. Cedergreen Bech (København: Gyldendal, 1982); Paulus Helie and A. Heise, Lektor Povl Helgesens Historiske Optegnelsesbog: Sædvanlig Kaldet Skibykrøniken, (København: Karl Schønberg, 1890-91), 44-45, n. 1.

24 Carl Ferdinand Allen, De Tre Nordiske Rigers Historie: Under Hans, Christiern Den Anden, Frederik Den Første, Gustav Vasa, Grevefeiden. 1497-1536, Trykt utgave. ed., 5 vols, De Tre Nordiske Rigers Historie (Kjøbenhavn: Gyldendalske, 1864-72), 1:158; Rørdam, “Danskes rejser til det Hellige Land,” 484. 25 Rothe, Brave danske Mænds, 1:657. 
of Stockholm - or the Stockholm massacre - but it cannot be stated with any certainty.

Not all, of course, went for such specific penitential purposes - or at least they are now unknown. Probably just as many went out of devotion alone. Many were knighted at the Holy Sepulchre as were nobles from all over Europe. Henrik Nielsen Rosenkrantz (d. 1537) was knighted in Jerusalem in 1522 and his letter of knighthood has been preserved. ${ }^{26}$ The dubbing of knights at the Holy Sepulchre had probably been performed since the twelfth century and it became increasingly popular during the fourteenth century. Towards the end of the fifteenth century, the pope handed over the privilege of dubbing knights to the Franciscans, but although the knights performed a vow, received special privileges, and their names were drawn up in a roll, one cannot speak of a knightly order before the middle of the sixteenth century. ${ }^{27}$ The ritual towards the end of the fifteenth century is described in several travel accounts, for instance by Arnald von Harff. ${ }^{28}$ A more elaborate liturgy is found in Franciscus Mennenius' work on knightly orders. In the 1613 version the knights also vowed to defend and protect the holy Church and to fight the enemies of the Christian name and Christian faith. ${ }^{29}$ The pilgrimage tradition and being created a knight at the Holy Sepulchre was thus an integral part of the religious practice of the nobility both before and after the Reformation in Denmark.

26 Konrad Barner, Familien Rosenkrantz's historie, 2 vols (Copenhagen, 1874-82), 2:54-55 (no. 45). 27 V. Cramer, "Der Ritterschlag am Hl. Grabe," in Das Heilige Land in Vergangenheit und Gegenwart 2 (Köln: Bachem, 1940); V. Cramer, "Das Rittertum vom Hl. Grabe im 14. Und 15. Jahrhundert," in Das Heilige Land in Vergangenheit und Gegenwart (Köln: Bachem, 1941); V. Cramer, "Das Rittertum vom Hl. Grabe im 16. Jahrhundert," ibid. (1949). "Der Ritterorden vom Hl. Grabe vom Beginn des 17. Jahrhundert bis zur Reform durch Pius X. 1600-1848," in Das Heilige Land in Vergangenheit und Gegenwart (Köln: Bachem, 1950); "Der Ritterorden vom Heiligen Grabe von den Kreuzzügen bis zur Gegenwart," in Palästinahefte des deutschen Vereins vom heiligen Lande (Köln: Bachem, 1952) [the last work was a summary without reference to the research presented in the other studies]; Kaspar Elm, "Kanoniker end Ritter vom heiligen Grab. Ein Beitrag zur Entstehung und frühgeschichte der palästinensischen Ritterorden,” Vorträge und Forschungen 26, Die Geistlichen Ritterordens Europas (1980), 142-46. A Danish heraldic study of the Jerusalem Cross treats the order briefly: O. H. M. Baron Haxthausen, "Jerusalemkorset," Heraldisk Tidsskrift 1 (1960), 303-04.

28 Arnold Harff and Malcolm Letts, The Pilgrimage of Arnold Von Harff, Knight: From Cologne through Italy, Syria, Egypt, Arabia, Ethiopia, Nubia, Palestine, Turkey, France, and Spain, Which He Accomplished in the Years 1496 to 1499, Works (Hakluyt Society) vol. 94 (London: n.pub., 1946), 202.

29 Franciscus Mennenius, Deliciæ equestrium ordinum, (Köln, 1613), 43-49. Cf. the slightly later version, Militarium ordinum, (Köln, 1623), 21-24. Mennenius's description of the Danish Order of the Elephant suggests that he knew the collar in its pre-Reformation shape. It made Erich Christian Werlauff and C. F. Wegener, Om danebrog og danebrogsordenen: en historisk undersøgelse (Copenhagen: Gyldendal, 1872), 83-84, think that Mennenius had his information concerning the order from Christian II while he was in the Netherlands. Werlauff also speculated on earlier editions of his work, but I have not come across any dated earlier than 1613. 


\section{Sixteenth-Century Post-Reformation Travels to Jerusalem}

After the Reformation, These journeys of the nobility had to be explained from the perspective of the Lutheran-Evangelical confession rather than from the possible original penitential motives of the pilgrims. In the Protestant eulogies for instance the emphasis was placed on the aspect that the nobles undertook these journeys more for the sake of learning about other cultures than for the sake of religion, which of course would be the official explanation. The noble Johan Rantzau (1492-1565) for example who was knighted at the Holy Sepulchre in 1517 - was praised for having travelled all over the world not for the sake of religion but in order to learn the art of war and other people's customs. ${ }^{30}$ The same motives were recorded in a later biography that explicitly excused that Johan still at that time was stuck in the "päbtslichen Irrthümern". ${ }^{31}$ Mogens Gyldenstierne was praised in his eulogy for having visited many countries on his way to the Holy Sepulchre in Jerusalem - among others Cyprus and Rhodes - to gain knowledge of other peoples and their customs, which he used in the service for his patria. His eulogy was written by the Danish theologian Niels Hemmingsen (1513-1600) and published in 1570. It is noteworthy that the purpose of the journey appeared quite clearly as a visit to the Holy Sepulchre, where Mogens Gydenstjerne as mentioned was knighted and later bathed in the River Jordan. ${ }^{32}$

It appears as if there was a pause in the journeys to Jerusalem in the decades after the Reformation, but in the last quarter of the century they re-appear in the sources. ${ }^{33}$ Between 1578 and 1580 the noble Gert Rantzau (1558-1627) visited the Holy Sepulchre where his grandfather Johan Rantzau had also been knighted. He had travelled from Constantinople via Rhodes, Cyprus, Tripoli, and Jaffa - from where the prophet Esaia set sail, as he commented - before going to Jerusalem, where he saw all of the holy sites. He went to the Mount of Olives, Calvary, bathed in the River Jordan, and saw the Dead Sea. He was on his way to Mount Sinai when disease in his entourage forced him to return and on his way back he visited Lebanon and Damascus. ${ }^{34}$ In 1587, Steen

30 Christianus Cicilius Cimber, Belli Dithmarsici (Basel: Samuel Regius, 1570), 259-60. Cf. Bring, Om valfarterna och korstågen, 179-81. On Johan Rantzau, see also Andersen Oftestad's introduction to this volume, Chapter 1, 13-16.

31 Otzen, "Johan Rantzau og andre adelsmænd i Jerusalem," 66.

32 Rothe, Brave danske mænds, 1:657.

33 The fall in the numbers of pilgrims was even commented upon by some contemporaries like the French noble Greffin Affagart (c.1490-1557) who blaimed the heresy of the "wicked lecher Luther" in his Relation de Terre Sainte (1533-34), cf. Chareyron, Pilgrims to Jerusalem in the Middle Ages, 39-40. 34 He left an account of his journey in his diary, which apparently has not been preserved, but is described in his eulogy by Antonius Burchard printed in 1629. There is an abbreviated account of his itinerary in the Middle East in Danske Magazin 4 (1750): 98-100. It says that he saw the Red Sea, which is likely, but as it is mentioned in connection with his bath in the River Jordan it probably should read the Dead Sea. 
Bille to Billesholm (1565-1629) visited Jerusalem. Back in Trondheim in Norway he proudly paraded in the clothes he had used on the same journey, probably some that had been adapted to represent local habits in the Orient. ${ }^{35}$

The Danish noble Sigvard Grubbe (1566-1636) met his peers Christian Barnekow (1556-1612) and Jacob Ulfeldt (1567-1630) in Venice in the 1580s while they were embarking on a trip to the Holy Land. According to his diary, Sigvard was keen on joining them, but he had already made other arrangements. He tried to make a change of plans but was bound by his word of honour, and despite trying to be released from his former agreement, he was left to wave on the shore while his Danish friends sailed off, ${ }^{36}$ thereby missing some interesting journeys. Christian Barnekow went all the way to Ethiopia after having seen Jerusalem. On his way to Jerusalem he travelled via Rhodes and Cyprus to Syria. From here to Aleppo, Tripoli, Lebanon, Mount Carmel, Jaffa, and through Ramla to Jerusalem "as a true Jørsalafarer [the old Nordic word for a crusader or Jerusalem pilgrim] as it was said in this country in old days." ${ }^{37}$ Jakob Ulfeldt also fought in the ranks of the Knights of Saint John together with his brother Mogens (1569-1616) in 1588-89 on his way to Syria and Egypt. A handwritten account of the journey exists at the Royal Library in Copenhagen, which in vivid detail describes all of the biblical sites in and around Jerusalem. In this account, Otzen explains, the travellers distance themselves from the legends related by the locals, but agrees that the scepticism becomes less marked although not totally disappearing when they enter Jerusalem and its vicinity. ${ }^{38}$ Nonetheless, they still faithfully record everything they see including detailed descriptions of the Church of the Holy Sepulchre as well as Jerusalem and its surroundings.

\section{The Journey of Otto Skram}

Perhaps the best example is the account of the Jerusalem journey of the noble Otto Skram. ${ }^{39}$ It is now known through a number of manuscripts, most of them later

35 N. Nicolaysen, Norske Stiftelse. Samling af Fundatser, Testamenter, Gavebreve, samt historisk-statistiske Efterretninger vedkommende milde Stiftelser i Kongeriget Norge, vol. 3 (Christiania: Chr. Tønsbergs Forlag, 1858), 859-60. Cf. Helk, Dansk-Norske studierejser, 39.

36 Holger F. Rørdam, ed., "Sigvard Grubbes Dagbog," Danske Magasin 4, 2 \& 4 (1873-78), 376.

37 C. F. Bricka and S. M. Gjellerup, Den danske Adel i det 16de og 17de Aarhundrede. Samtidige Levnetsbeskrivelser uddragne af trykt og utrykte Ligprædikener, 2 vols. (København: Rudolf Klein, 1874-1913), 2:2-20. On terminology, see volume 1, Chapter 2 (Klaus Johan Myrvoll).

38 KB Thott $12944^{\circ}$. It has not been published. Cf. Otzen, "Johan Rantzau og andre Adelsmænd i Jerusalem," 76-78. However, even some Catholic contemporaries explicitly stated that "faith and belief" were prerequisites for believing all they were told by their guides, cf. Chareyron, Pilgrims to Jerusalem in the Middle Ages, 88, quoting Greffin Affagart.

39 See also introduction to this volume, Chapter 1 (Eivor Andersen Oftestad), 42-44. 
(eighteenth-century) copies and translations into Danish. ${ }^{40}$ Originally it might have been written in German. In 1587, he initiated the journey that would eventually take him to Jerusalem. First he went to Vienna, where he served in the expedition that was led by Maximillian III of Austria (1558-1618) into Poland. He describes in some detail the movements of the army, pitched battles, and other parts of life during a military campaign. In the end, they are defeated and he is ordered to serve as guard at the border into Poland. He was given leave and moved on to Breslau and then to Prague before returning to Vienna. Still in the service of his master, he travelled to Italy in 1589 when the king of Spain hired people in Portugal. The same year, he returned to Vienna. He then took leave and travelled in the company of the imperial envoy to Constantinople, where he stayed until 1591. In that year he travelled in the name of God with his three companions from Constantinople to Jerusalem as "pilgrims." He then gave a detailed description of his tour through the Holy City and its vicinity, faithfully reporting the exact location of the many biblical events. Only in one place does a "si fides" [if you believe it] creep into the narrative. Finally, he was knighted by "Pater Guardiano" as a Knight of the Holy Sepulchre. His letter of knighthood gave him the privilege to carry "the insignia and coat-of-arms of the Holy Cross, the Holy Sepulchre, and Saint George, ${ }^{41}$ secretly and in public according to his own will. Hereafter, as a brave and legal knight he is privileged to enjoy and use all the liberties, rights, and privileges as other knights of the Holy Sepulchre usually do."42

After Otto Skram had been knighted, he went on to visit other important places in the Holy Land. Then he travelled through Europe back to his fatherland Denmark. In some of the manuscripts the text is followed by a learned note concerning the identity of Otto Skram based on the introduction to The Law of Jutland by the historian, jurist, and statesman Peder Hansen Resen published in 1684 and mentioned at the beginning of this article. His brother Poul Resen's information about the graffiti of "Otto Skram Danus 1599" written at the door of his accommodation must be amended to 1591 .

$40 \mathrm{~KB}: \mathrm{GkS} 30844^{\circ}$; KB: Kallske Saml. $6788^{\circ}$. The letter is still found in a Latin version: KB: Kallske Saml. $1282^{\circ}$. Skram's travel account is partially published by Glarbo, "Danske Palæstinafarere i det 16. og 17. aarhundrede," 21-32. after the oldest transcript (KB: NkS $21214^{\circ}$ ).

41 Cf. Mennenius, Deliciæ equestrium ordinum, 42; "S. Crucis Sanctissimique Christi Sepulchri ac S. Georgii insignia deferre.”

42 KB: GkS $30844^{\circ}$, fols. $26^{\text {r-v }}$ : "Före det Hellige Korse[s: NB! from KB: Kallske Saml. 678 8, fol. 131], den Hellige Gravs og Sti: Georgii insignia og Vaaben, hemmelig og offentlig, som det hannem selv got siynes, og Han her efter som en tapper og lovlig Ridder med billighed og ret at maa nyde og bruge alle de friiheder, Höiheder, og privilegier, som andre den Hellige Gravs riddere pleier at nyde og bruge"; KB: Kallske Saml. $1282^{\circ}$ : "decernentes insuper Dominum Ottonem Schram à Dano, de cetero libere deferre posse, Sanctæ crucis, Sancti Sepulchri ac Sancti Georgii insignia, secrete aut publice, prout sibi videbitur, nec non in futurum ut verum ac legittimum Militem omni dignitate, Jure optimo frui valere ac debere, omnibus et singulis immunitatibus, præeminentiis ac privilegiis, quibus ceteri Milites Sancti Sepulchri uti ac frui consverere.” These privileges are important and perhaps it is possible to identify more Protestant knights through the use of these symbols. 
Peder Hansen Resen had personally read in an old genealogy that was owned by "Mr. Bircherod" [Thomas Broder Bircherod (1661-1731)] of a noble named Otto Skram of Hammergaard, who had travelled a lot, especially in the Orient. According to the old genealogy, he was stabbed to death in the streets of the Danish city of Viborg by a parish priest by the name of "Mr. Søren in Hornum". Resen believed this to be the same Otto Skram who was mentioned by his brother and identified by later transcribers of the travel account with its author. ${ }^{43}$

The account is fascinating for its details concerning the visits to the holy sites in Jerusalem. The same applies to the account of Ulfeldt and Barnekow. Other accounts are more brief, but I would like to suggest that all of the Danish nobles probably experienced the same tour of the Holy City and the scenes of Christ's passion according to the plan of the Franciscan custodians that often functioned as guides. ${ }^{44}$ This of course does not automatically turn the journey into a pilgrimage. However, at least to contemporaries who were careful not to present their journeys as pilgrimages in the Catholic sense, there was an identification with the former practice of the Jerusalem journey of the Middle Ages. Many of the nobles were also knighted at the Holy Sepulchre. At least some connection was seen in the sixteenth century between being knighted at the Holy Sepulchre and the creation of Equites Aurati golden knights - the common term for knighthood in Denmark. At his coronation in 1559, Frederik II (1559-88) created several "golden knights". ${ }^{45}$ Johan Rantzau "received the dignity of a golden knight" when he was knighted in Jerusalem. ${ }^{46}$ The later archbishop in Lund, Mogens Madsen (1527-1611), wrote in his historical work Regum Daniæ Series from the second half of the sixteenth century concerning King Valdemar IV (1346-76) that he fought against the Lithuanians in Prussia, and that he went on a pilgrimage to Jerusalem where he was knighted, "which we call golden knight", by Count Erik of Saxony (1354-1412). ${ }^{47}$ Sigvard Grubbe wrote in his diary that the noble Jørgen Lykke of Overgaard (1515-83) was an Eques Auratus and the last of this order in Denmark towards the end of the sixteenth

43 Peder Hansen Resen, Kong Valdemar den Andens Jysk Low-Bog (Copenhagen: Neuhof, 1684), preface, not paginated.

44 Marianne P. Ritsema van Eck, “Custodians of Sacred Space: Constructing the Franciscan Holy Land through Texts and Sacri Monti (ca. 1480-1650),” (PhD diss., University of Amsterdam, 2017).

45 Frans Hogenberg, "Res gestæ serenissimi potentissimique principis ac domini Frederici II. etc.," (1589), PL 6; Janus Bircherod, Breviarium equestre (Copenhagen: Johs. Laverentzen, 1706), 22-23.

46 Cimber, Belli Dithmarsici, 258-59.

47 Mogens Madsen, “Regum Daniæ Series,” ed. Holger Fr. Rørdam, Monumenta Historiæ Danicæ. Historiske Kildeskrifter og Bearbejdelser af dansk Historie. Især fra det 16. Aarhundrede (Kjøbenhavn: G. E.C. Gad, 1873-87), 131-32. On Mogens Madsen as a critical historian, cf. Holger Fr. Rørdam, Historieskrivningen og historieskriverne i Danmark og Norge siden reformationen: 1: Tidsrummet fra reformationen indtil Anders Vedel, vol. 1 (Kjøbenhavn: Vilhelm Tryde, 1867), 57-60. 
century. ${ }^{48}$ It does actually appear as if the practice and tradition of being knighted at the Holy Sepulchre disappeared in the early seventeenth century. However, nobles continued to visit Jerusalem to see the holy sites.

\section{Jerusalem Journeys in the Seventeenth Century}

The Jerusalem journey was not just for nobles. A certain Jens or Janus Skierbæk (1553-1633) from Flensburg who later became a doctor in Lübeck visited Palestine and the holy places as well as undertaking extensive travels in Asia Minor and North Africa according to his epitaph. ${ }^{49}$ In 1619, the writer Henrik Albertsen Hamilton (d. 1623), who was a son of the mayor of Copenhagen, Christen Albertsen (1567-1616), travelled to the courts of Europe and beyond. He died of disease in Egypt like Poul Resen, probably in $1623 .^{50}$ It is, however, primarily the journeys of the nobility that we know of. Steen Olufsen Rosensparre (1588-1612) wanted to continue to Jerusalem while visiting Venice in 1609 , but was prevented in part due to the dangers of the travel including Turkish corsairs. ${ }^{51}$ Between 1613 and 1615, the noble and later colonel in the army of Christian IV (1588-1648), Frederik Rantzau (1590-1645), visited Jerusalem. For unknown reasons he travelled in a caravan from Constantinople over land to the Holy Sepulchre through Asia Minor and Syria before reaching Jaffa and Jerusalem, where he visited the holy places. From there he went to Cairo where he saw the pyramids, across the desert to Sinai before leaving for home on an English ship from Alexandria. On his way home, he visited the Hospitallers on Malta. Besides continuing the family tradition for visiting Jerusalem, he had travelled on official business to Spain before leaving for the Holy Land in the company of Jakob Ulfeldt, who probably had told him of his own travels in the Orient. ${ }^{52}$ The noble and bellicose Jesper Friis (1593-1643) travelled to Turkey, Egypt, Arabia, and Palestine around 1618. ${ }^{53}$

48 Madsen, “Regum Daniæ Series,” 367.

49 Pontoppidan, "Gesta et vestigia Danorum," 1:61 and 3:321-23.

50 Jens Worm, Forsøg til et Lexicon over danske, norske og islandske lærde Mænd (København: August Frieder Stein, 1771-84), 1:15-16; Holger F. Rørdam, “To Kjøbenhavnske Borgmestre," Personalhistorisk Tidsskrift 2, no. 2 (1887), 299; Helk, Dansk-Norske studierejser, 33, 233.

51 Rothe, Brave danske mænds, 1:50, 54.

52 Hans Mikkelsen, En christelig Lijgprædicken aff Wijssdommens Bogs 5. Cap. Der Oberste Fredrich Rantzow til Assdal, hans Lijg bleff nedersat udi Sanct Knuds Kircke udi Odense den 4. Februarii 1645 (Hamburg: Melchiore Martzan, 1647); copy in manuscript in the Royal Library in Copenhagen, MS Uldall $444,4^{\circ}$. The description of the stay in Jerusalem and the things he saw - the Holy Sepulchre, the Mount of Olives, Bethlehem the burial place of the Kings - is very brief. He definitely saw many more places, but Hans Mikkelsen comments that it would "go too far to mention them all here," ibid., 96-98.

53 Hans Mikkelsen, En christelig Lijgprædicken, aff den 51. Kong Davids Psalme, der Jesper Frijs til Ørbeck-Lunde bleff bestædet i S. Knuds kircke i Ottense d. 6. Maij 1643 (Hamburg: Peter Hake, 1645), 
There is a tendency from the end of the sixteenth century that the journeys of the nobility included destinations apart from Jerusalem. They continue further to Jordan, Syria, and Egypt, and some even to Ethiopia. It is obvious that several of the destinations are still motivated by stories from the Bible especially the Old Testament, but the pyramids, antiquities, and strange animals were also commented on. For instance, Jesper Friis to Ørbæklunde went from Venice to Constantinople in 1617 and from there he went into the Black Sea to see antiquities. Later he sailed to Alexandria and saw Cairo and the pyramids. He went on to Mount Sinai where the Old Testament stories and events came alive to him.

In 1623, the noble Henrik Rantzau (1599-1674) visited Jerusalem and Egypt, but his travel account was first published in $1669 .{ }^{54}$ He celebrated Easter in Jerusalem and afterwards he visited the many places of worship in and around the city. He was not knighted at the Holy Sepulchre, but his observations still point to some interesting features of what was deemed to be of interest for a noble and educated traveller in the seventeenth century. The great battle at Lepanto was remembered when they reached "Corsolari Isole where the Turk in 1571 lost a great battle against Don Gio di Austria” [the Battle of Lepanto] on the journey through the Aegean Sea. He mentions the fear of Turkish corsairs and then goes on to describe in some detail the clothes and weapons of the Turks. They sailed from Cyprus on 27 March and reached the shores of Lebanon on the 28th. From there, they followed the coast passing Tripoli, Simon, and Tyre before reaching Acre "where the Templars once had their residence." He spent time looking at what he believed to be the great ruins of the palace of the Grand Master of the Temple and the Church of Saint John. At the church of the Holy Sepulchre, he saw the tombs of Godfrey of Bouillon and Baldwin I.

From Jerusalem, he moved on to Cairo. Near the hostel where he stayed was a church-tower, where Saint George was decapitated. He also went to see the saint's tomb outside of Cairo. To his great disappointment, he did not get to see any crocodiles or hippopotamuses. Both were supposed to be very tasty, he comments. Generally, Rantzau shows great interest in fortifications, but he also describes in detail churches and mosques. He is a keen observer of customs and he reports a lot about animals. Rantzau seems much more a man of the world than a pilgrim in the 1669 version of his travel account. Only very few pilgrimage elements remain, which are interestingly those connected to the knightly Saint George and the heroes of the First Crusade, Godfrey and Baldwin. ${ }^{55}$ Simultaneously there was an outspoken interest in what could be termed pilgrimage and crusade literature.

125-30. A description of the journey is found at the Royal Library in Copenhagen, KB, NkS 371, $8^{\circ}$, cf. Helk, Dansk-Norske Studierejser, 39.

54 Henrik Rantzau, Reise-Buch auff Jerusalem/Cairo in Agypten und Constantinopell (Copenhagen: Christian Wering, 1669).

55 Could it be that special interest in Godfrey and Saint George might be an indication that Rantzau was in fact knighted at the Holy Sepulchre? 


\section{Pilgrimage and Crusade Literature}

The interest in the pilgrimage tradition was still alive in the decades after the Reformation, at least in literature even if people no longer went in person to Jerusalem. The Franciscans in Denmark translated Mandeville's Travels into Danish in the middle of the fifteenth century. The surviving five manuscript copies, however, all date from the second half of the sixteenth century, witnessing the continued interest in the story. ${ }^{56}$ One of the Danish manuscript versions of Mandeville's Travels is an abridged version from the second half of the sixteenth century that particularly focuses on the pilgrimage to Jerusalem, reflecting the continuing interest in the Jerusalem pilgrimage. ${ }^{57}$

More importantly perhaps, the introduction to the Danish version, like the original, also exhorted for renewed war against the Turks in order to win back Jerusalem. Special focus was given to the Danish hero, Ogier the Dane, who was one of the twelve peers of the ninth-century emperor Charlemagne, and his deeds as champion of Christendom. He became a role model, as Charlemagne, Roland, and Godfrey of Bouillon were in Europe in general even in the sixteenth and seventeenth centuries to crusaders like the conqueror of Mexico, Hernan Cortez, and other nobles. ${ }^{58}$

Ogier played a central role as a champion of the faith in the creation of a Danish national historical discourse. In this the war against the enemies of the faith formed an important part, and Jerusalem figured prominently.

\section{Ogier the Dane as a Crusader Hero}

The stories of Ogier the Dane as a crusader or champion of the faith became part of one of the manuscript traditions of Mandeville's Travels towards the end of the fourteenth century. In 1481 this role was stressed in the printed German translation

56 S. A. J. Bradley, “The Translator of Mandevilles Rejse: A New Name in Fifteenth-Century Danish Prose?," in Medieval Literature and Civilization: Studies in Memory of G. N. Garmonsway, eds. D. A. Pearsall and R. A. Waldron (London: Bloomsbury, 1969).

57 S. A. J. Bradley, ed. and trans., The Danish Version of "Mandeville's Travels" in Sixteenth-Century Epitome (Lewiston: E. Mellen Press, 1999), 24-25.

58 The expansion in the New World and India and Asia in the sixteenth and early seventeenth century was also legitimized as crusades. Cortez wrote letters in which he compared himself and his struggles to those of Roland, was obsessed with conversion, and his army carried banners of the cross, cf. Jennifer R. Goodman, Chivalry and Exploration, 1298-1630 (Woodbridge: Boydell, 1998); Norman Housley, The Later Crusades, 1274-1580: From Lyons to Alcazar (Oxford: Oxford University Press, 1992), 312. 
by von Diemeringen. ${ }^{59}$ In this version, his role as miles Christi is also stressed: "He called himself God's soldier, for he fought not for countries or power, but only that he convert people to Christianity."60

The role of Ogier the Dane became much more prominent in the Latin version of Mandeville's Travels and subsequently in the Danish translation. The latter related that after Ogier the Dane's mysterious disappearance from the court of Charlemagne around the year 800, he conquered all countries from Jerusalem to Paradise, which were believed to be placed in the far East, ${ }^{61}$ in the company of "fifteen other nobles of his kin and with 20,000 men" and converted them to the Christian faith with the aid of God. ${ }^{62}$ Some "unreasonable people" believed that Ogier was still alive somewhere in the world, the author wrote: "But I find it more plausible that he lives with God in heaven because he worked so hard for the holy faith and the extension of Christendom."63

In a brief historical work attributed to the court historiographer of Christian II, Christiern Pedersen (1480-1554), dated 1521, the deeds of Ogier the Dane as a champion of the Christian faith are strongly underlined: "He fought the heathens continuously [...] and shed his blood for the sake of God." ${ }^{64}$ It was also cited by the Franciscan historian Petrus Olai in his Chronica Regum Danorum from the 1520s and he further relates how Ogier the Dane had conquered all the lands from "around Jerusalem, which is the navel of the world, all the way to India”, converted them to the Christian faith, and made them tributary. "This is testified by John of Mandeville, who personally visited those parts from Jerusalem to Greater India near Paradise.”65

The stories concerning Ogier the Dane, that probably formed the basis for the version in Mandeville, existed in many different forms. ${ }^{66}$ They were gathered and

59 Kirsten Lading Bidsted, “Holger danske i skævinge,” ICO, Iconographisk Post 1 (1989); Malcolm Letts, Mandeville's Travels: Texts and Translations, 2 vols. (London: Hakluyt Society, 1953), 1:xli-xlvi. Von Diemeringen's passages concerning Ogier are printed ibid., 2:483-94.

60 Mandeville's Travels: Texts and Translations, 486.

61 On the geographical location of Paradise, see Alessandro Scafi, Mapping Paradise: A History of Heaven on Earth (London: The British Library, 2006). See also Introduction to this volume, Chapter 1 (Eivor Andersen Oftestad), 20-23.

62 Lorenzen and Mandeville, Mandevilles Rejse, 5, 162.“andræ femten herræ aff sith slektæ ok met tyuæ tusindæ wæpnæræ.”

63 Lorenzen and Mandeville, Mandevilles Rejse, 191: "Jek tror bætær, at han lefuer met gudh udi hemmærigæ, effter thy at han arbeydede sa megit for then helly troo oc cristendoms merelssæ skill."

64 C. J. Brandt and R. T. Fenger, Christiern Pedersens danske skrifter, 5 vols. (København: Gyldendal, 1850-1856), 5:336, 50-53: “[Han] idelige bestride hedninge [. . . ] och wdgaff sit blod for Guds skyld.” 65 Petrus Olai, Chronica regum Danorum, ed. Jakob Langebek and Peter F. Suhm et al., 9 vols., vol. 1, Scriptores Rerum Danicarum Medii Ævi (Copenhagen, 1772-1878), 72.

66 Cf. Kurt Villads Jensen, Crusading at the Edges of Europe: Denmark and Portugal, c. 1000-c. 1250 (London: Routledge, 2017), 208-15; Janus Møller Jensen, Denmark and the Crusades, 1400-1650, The Northern World 30 (Leiden: Brill, 2007); “King Erik Emune (1134-1137) and the 
translated into Danish by Christiern Pedersen, who had become a follower of Luther in the 1520s, most likely during his second stay in Paris around 1527 and published as Holger Danskes Krønike [The Chronicle of Ogier the Dane] in Malmö in $1534 .{ }^{67}$ In this version, Ogier fought against the Turks outside Rome: Charlemagne came to Rome as head of an army to fight against the Turks to "prove that they were Christian men," and Ogier the Dane fought for the holy Christian faith against the Turks. ${ }^{68}$ In his capacity as miles Christi and proto-crusader, Ogier functioned almost as a post-Reformation national saint, and he was depicted on several murals like "the nine worthies" also known from Danish wall-paintings of the early sixteenth century. Ogier and the other heroes could be used in political propaganda and as role models for youths both before and after the Reformation. ${ }^{69}$

Just prior to the publication of Ogier's chronicle, Christiern Pedersen had published Kejser Karl Magnus Krønike [The Chronicle of Charlemagne] also in Malmö in 1534, mainly because the subject appealed to him:

It told of the deeds in war and battle of the great emperor in company with the twelve peers and other Christian giants, knights and good able courtiers and warriors against the Turks and heathens and many more enemies of the holy Christian faith, who wanted to subjugate and destroy Her [the Christian faith], and how he deliciously defeated and killed several thousands of these heathens in war and battle by the assistance, comfort and mercy of God. ${ }^{70}$

The Chronicle of Charlemagne was a Danish translation of the Old Norse Saga of Charlemagne. It was translated in the Danish monastery of Børglum in 1480. It was published in Danish by Gotfred of Ghemen (d. 1510) in 1501, and according to Christiern Pedersen again in 1508 and $1509 .{ }^{71}$ Although he did change some of the most Catholic elements in these stories, in his version from 1534, to fit his new beliefs, he left enough to be criticized by fellow Protestants - for example, the heroes' veneration of saints and relics. However, he harshly rejected such criticism. Even if these heroes had been deceived by false preachers to put faith in saints and call for their help, they considered themselves to be good Christians and proved it by

Crusades: The Impact of Crusading Ideology on Early Twelfth-Century Denmark," in Cultural Encounters During the Crusades, eds. Kurt Villads Jensen, Kirsi Salonen, and Helle Vogt (Odense: University Press of Southern Denmark, 2013).

67 Brandt and Fenger, Christiern Pedersens danske skrifter, 5:532-35; C. J. Brandt and Christiern Pedersen, Om Lunde-Kanniken Christiern Pedersen og hans skrifter (Copenhagen: Gad, 1882), 174-75, 269-73.

68 Brandt and Fenger, Christiern Pedersens danske skrifter, 5, 146-47.

69 Bidsted, "Holger danske i skævinge," 29-30.

70 Brandt and Fenger, Christiern Pedersens danske skrifter, 5:127. Cf. Brandt and Pedersen, Om Lunde-Kanniken Christiern Pedersen, 265-69.

71 Brandt and Pedersen, Om Lunde-Kanniken Christiern Pedersen, 266-67. 
risking their possessions and lives for the sake of religion, he argued. ${ }^{72}$ Even in this chronicle, Ogier played a central role as a champion of the faith, which places it alongside The Chronicle of Ogier as part of the national history.

When Christiern Pedersen published his Chronicle of Ogier the Dane in 1534, he expressed the hope that the work would inspire young Danish nobles to war. ${ }^{73}$ We know that it did. Henrik Holck studied in Sedan in 1618 together with numerous other young Lutheran nobles who prepared to fight for the evangelical union in the wars of religion, but he ended up as imperial field marshal twenty-five years later. As a child he always played "Christians and Turks" - war-games - inspired by "The Chronicle of Ogier the Dane and ballads telling of the adventures of old heroes" as was reported in a eulogy. ${ }^{74}$ This literature is important in forming the background for the travels of the nobility of the sixteenth and seventeenth century. The nobles also read about the historical crusades and the war to liberate Jerusalem and the Holy Land.

\section{Reading of Crusade Chronicles}

During the second half of the sixteenth century, a renewed interest in crusading history surfaced in Denmark. For instance, the chronicles of the First Crusade were being read. Several were being translated into the vernaculars in the fifteenth and sixteenth centuries. The chronicle of Robert of Rheims, for example, was translated into German in five independent versions in the fifteenth and sixteenth centuries, as well as into Dutch and Italian. ${ }^{75}$ Robert's chronicle was found in Scandinavia in at

72 Brandt and Pedersen, Om Lunde-Kanniken Christiern Pedersen, 273-78. From another perspective cf. Anders Sørensen Vedel's arguments based on a Melanchtonian perception of history for publishing the chronicle of Adam of Bremen in 1579, despite the fact that it described veneration of saints and relics and other papist practices, analysed in Karen Skovgaard-Petersen, "Skal den katolske fortid komme til orde? Anders Sørensen vedels dilemma ved udgivelsen af Adam Af Bremen i 1579," Fund og Forskning 43 (2004).

73 Brandt and Fenger, Christiern Pedersens danske skrifter, 134-35.

74 S. M. Gjellerup, “Kejserlig Feltmarschal Henrik Holck. En biografisk studie,” Historisk Tidsskrift 5, no. 4 (1884), 648-49.

75 Friedrich Kraft, Heinrich Steinhøwels Verdeutschung der Historia Hierosolymitana des Robertus Monachus: Eine literarhistorische Untersuchung, Quellen und Forschungen zur Sprach- und Culturgeschichte der Germanischen Vølker 96 (Strassburg: Trübner, 1905); Barbara Haupt, "Historia Hierosomlymitana von Robertus Monachus in deutscher Übersetzung," in Beiträge zur Literatur des XV. bis XVIII Jahrhunderts 3 (Wiesbaden: Steiner, 1972). The Anglican priest Samuel Purchas (1577-1629) translated in 1625 parts of it, as well as parts of the chronicles of William of Malmesbury and Matthew Paris that related to the crusade, Samuel Purchas, Hakluytus Posthumus or Purchas His Pilgrimes. Contayning a History of the World in Sea Voyages and Lande Travells by Englishmen and Others, vol. 22 (Glasgow, 1905-1907), 7:420-527. 
least two twelfth-century Latin versions. ${ }^{76}$ The first was placed in the royal library in Bordesholm where it had been transferred from the monastery of Neumünster in Holstein. The chronicle most certainly was read in the fifteenth century. At the scriptorium at Bordesholm, excerpts of the Gesta Francorum, which told of the conquest of Jerusalem, were being copied in the fifteenth century and bound together with the manuscript containing Robert's chronicle. ${ }^{77}$ The chapters of the Gesta Francorum copied at Bordesholm correspond to a series of chapters which are also found in the other extant manuscript version of Robert's chronicle found in Uppsala that also contains other parts of the Gesta Francorum. In the Uppsala manuscript the crusading chronicles are followed by a description of the Holy Land from the early twelfth century, a list of names of the bishops, patriarchs, kings (from Godfrey of Bouillon), and princes of the crusader states as well as the churches in Jerusalem and finally some texts about Pontius Pilate and Judas Iscariot. This manuscript was owned in the sixteenth century by the Danish royal chancellor Johan Friis to Hesselagergård $(1494-1570) .^{78}$

When Henrik Rantzau saw the tombs of Godfrey of Bouillon and Baldwin I, he undoubtedly was familiar with their stories. The great heroes of the First Crusade were still remembered among the Danish nobility; ${ }^{79}$ perhaps he had even read about them in the Chronicles of the First Crusade - either in manuscript form or as published by the French diplomat and historian Jacques Bongars in 1611, who did in fact visit Denmark as an ambassador and singled out Denmark as one of the crusading countries of all time. ${ }^{80}$ It is also very reasonable to think that he read about them in the great crusading poem Gierusalemme liberata by Torquato Tasso (1544-1595) that came out in numerous translations - although not in Danish (until the nineteenth century). ${ }^{81}$ Tasso's poem was cited as a source for the history of the First Crusade

76 KB: GkS $21594^{\circ}$ (from Bordesholm); UUB: C691.

77 KB: GkS $21594^{\circ}$. Cf. Ellen Jørgensen, Catalogus codicum latinorum medii ævi bibliothecæ regiæ Hafniensis (Copenhaden: Gyldendal, 1926), 381-82; August Wetzel, "Die Reste der Bordesholmer Bibliothek in Kopenhagen," in Die Klosterbibliothek zu Bordesholm und die Gottorper Bibliothek. Drei Bibliographische Untersuchungen, eds. Emil Steffenhagen and August Wetzel (Kiel: Commisionsverlag der Universitäts-Buchhandlung, 1884), 153-55. The latter dates the fragment to the fourteenth century, but I agree with Jørgensens's dating to the fifteenth century.

78 UUB: C691. Cf. Andersson-Schmitt, Hedlund, and Hallberg, Mittelalterliche Handschriften Der Universitätsbibliothek Uppsala, 6:298-301.

79 As early as the 1490s, Swedish prelates fantasized that a part of the papal crusading army being planned at the time was going to be directed against the Russians "as in the time of Godfrey of Bouillon," Handlingar Rörande Skandinaviens Historia, 40 vols. (Stockholm: Elméns och Granbergs Tryckeri, 1816-60), 1:76. Cf. Gøsta Kellerman, Jakob Ulvsson och den svenska kyrkan under Aldre Sturetiden 1470-1497: 1: under Fldre Sturetiden 1470-1497, vol. 1 (Stockholm: SKD, 1935), 182-83.

80 Jacques Bongars, Gesta Dei per Francos sive Orientalium expeditionem et regni Francorum Hierosolimitani historia (Hannover: Wechel, 1611).

81 Torquato Tasso, “Gerusalemme Liberata” (Ferrara, 1581); Cf. Charles P. Brand, Torquato Tasso: A Study of the Poet and of his Contribution to English Literature (Cambridge: Cambridge University 
well into the nineteenth century. ${ }^{82}$ But many other possibilities are ready at hand, like the German Johan Carion's Weltchronik that was read in German and came in several Danish translations, or other historical works that he and other nobles undoubtedly would have access to. ${ }^{83}$

The publication and compilation of crusade texts was often intended to arouse renewed crusades against the Turks. ${ }^{84}$ For example, Robert's chronicle was translated into German as late as 1584 in an anonymous work the main aim of which was to call to resistance against the Turks and encourage re-conquest of the lands lost to them. ${ }^{85}$ It also served as one of several sources for the German Zimmerische Chronik, written by the count of Zimmern, Froben Christoph (1519-66) in the sixteenth century telling of his family ancestors' as well as a number of German nobles' participation in the First Crusade. As Alan V. Murray has argued, Froben Christoph's information about the German participation "is dubious in the extreme," but he testifies to the "perception of the First Crusade in Germany in the late medieval and early modern period" in face of the Turkish advances, when he turned "the genesis of the entire crusading movement into an enterprise initiated by a faithful servant of the German emperor, in which the bravest and best fighters were German." ${ }^{86}$ The same can be seen in Denmark.

Press, 1965), 54-55. For the crusade at Tasso's time, see Housley, The Later Crusades, 1274-1580, 118-50; Kenneth M. Setton, The Papacy and the Levant, 1204-1571, 4 vols. (Philadelphia: American Philosophical Society, 1976-84), 4:829-1104.

82 Elizabeth Siberry, The New Crusaders: Images of the Crusades in the Nineteenth and Early Twentieth Centuries, The Nineteenth Century (Aldershot: Ashgate, 2000); "Nineteenth-Century Perspectives of the First Crusade," in The Experience of Crusading, Vol. 1: Western Approaches, eds. Marcus Bull and Norman Housley (Cambridge: Cambridge University Press, 2003).

83 Johan Carion, Chronica M. Johan Carion paa thet flittigste sammen dragen, huer mand nytteligt att læse oc er nu fordansket aff M. Joenn Tursson: Medt een skøn oc herlig register som indholler alle fornemste handel oc Historier som seg fraa Verdens begyndelse ind til Carolum $V$ begiffuit haffue (Wittenberg: Jurgen Rhauues arffuinger, 1554), 208; Johan Carion, Chronica. Forbedret aff Philippo Melanthone (Copenhagen, 1595), 145v-47v; Albert Krantz, Chronica Regnorum Aquilonarium: Daniæ, Suetiæ, Norvagiæ (Strassburg: Hans Schotten, 1546), 179; Cornelius (the younger) Hamsfort, Rebus Holsatorum vicinarumque gentium præclare gestis, Libri IV, ed. Ernst Joachim de Westphalen, Monumenta inedita rerum Germanicarum præcipue Cimbricarum et Megapolensium (Leipzig: Johann Christian Martini, 1739-1745), 1680 telling of Godfrey and the First Crusade. Krantz was later also quoted by Lambertus Alardus, Nordalbingia, ed. Ernst Joachim de Westphalen (Leipzig, 1739-1745), 1772-1773, telling of Godfrey and the crusade. On Carion's Chronicle, see also the introduction to this volume, Chapter 1.

84 Cf. for instance G. Burger, ed., A Lytell Cronycle: Richard Pynson's Translation (1520) of Hethoum's 'La Fleur Des Histoires De La Terre D'orient' (Toronto: Toronto University Press, 1988); Christopher Tyerman, The Invention of the Crusades (Basingstoke: MacMillan, 1998), 104-05.

85 Haupt, "Historia Hierosomlymitana von Robertus Monachus," 227. Cf. Tyerman, The Invention of the Crusades, ed. Reinier Reineck (1541-1595), 105-06.

86 Alan V. Murray, "The Chronicle of Zimmern as a Source for the First Crusade: The Evidence of the Ms Stuttgart, Württembergische Landesbibliothek, Cod. Don. 580," in The First Crusade: Origins 
In 1584, the Danish historian Anders Sørensen Vedel (1542-1616) wrote a preface in Latin to a twelfth-century copy of the chronicle of Robert of Rheims that he planned to publish. There can be no doubt that the purpose of his publication of Robert's chronicle was to incite to war against the Turks as well as to inspire young Protestant nobles to follow the example set by the first crusaders fighting for the faith when they captured Jerusalem on the first crusade. Apparently, his work was never published but the foreword still exists in manuscript bound together with the chronicle. ${ }^{87}$ The manuscript also contains a very beautiful map of Jerusalem. Vedel further had a printed version at his disposal, which he compared with his manuscript. He dedicated his work to a young noble named Erik, probably the alchemist Erik Lange (d. 1613), and encouraged him to follow the example set by the first crusaders when they won the palms of martyrdom in the Holy Land in battle against the Turks. ${ }^{88}$

This would not at all have been a strange thought for a young Lutheran noble. Martin Luther promised that those who died in battle against the Turks would become martyrs and saints. Luther claimed that if you went to war in obedience to your lord at God's will and command, you would become the executioner of God and your hand and lance would be the hand and lance of God. ${ }^{89}$ Or one is tempted to say: gesta Dei per Lutheranos. It was only natural that this idea would develop into the general concept that death in war for the patria would lead to martyrdom. ${ }^{90}$ It surfaces in a broad range of different sources in Denmark, like the old folk ballads that became extremely popular among the nobility towards the end of the sixteenth century and which describe how fighting for the king and country resulted in heavenly rewards. ${ }^{91}$ Another example would be rhymed family chronicles like Billeslægtens Rimkrønike [The Rhymed Chronicle of the Bille Family], written by the poet and historian C. C. Lyschander (1558-1624) at the beginning of the seventeenth century. It

and Impact, ed. Jonathan Phillips (Manchester: Manchester University Press, 1997), 91-92. Cf. Alan V. Murray, "Deutsche Anführer beim ersten Kreuzzug in der Geschichtsschreibung der frühen Neuzeit. Zur Kreuzzugsdarstellung der zimmerischen Chronik,” Zeitschrift für Württembergische Landesgeschichte 61 (2002).

87 UUB: C691. Edited by Jørgensen 1909-11, 777-85 and in RHC Occ.: 3:lii-lv. I would like to thank Karen Skovgaard-Petersen for initially providing me with a copy of the manuscript.

88 Vedel knew the printed version of Henricus Petri from 1533. For the preface, see now Karen Skovgaard-Petersen, "A Lutheran Appropriation of the First Crusade: The Danish Historian Anders Sørensen Vedel's Apology for an Edition of Robert of Rheims," in Fighting for the Faith - the Many Crusades, ed. Kurt Villads Jensen, Carsten Selch Jensen, and Janus Møller Jensen (Stockholm: Sällskapet Runica et mediævalia, Centre for Medieval Studies, 2018).

89 WA 30/2,174,12-22.

90 Cf. Norman Housley, "Pro Deo et Patria Mori: Sanctified Patriotism in Europe, 1400-1600," in War and Competition between States, ed. Philippe Contamine (Oxford: Oxford University Press, 2000). 91 Cf. Anders Sørensen Vedel, Hundredvisebog (København: Reitzel, 1993). On the folksongs, see Flemming Lundgreen-Nielsen and Hanne Ruus, eds., Svøbt i mår. Dansk folkevisekultur 1550-1700, vol. 4 (København: Reitzel, 1999-2002). 
assured the reader that if you died in war against the Swedes you would become a martyr and go straight to heaven. ${ }^{92}$

\section{The Ringsaker Tabernacle}

The theme of martyrdom and the war against the Turk on the general background of crusading history was also expressed in church art. A fascinating example is the tabernacle from the Norwegian Ringsaker Church. The church was placed on one of the main arteries of communication in Norway in a north-south direction. Originally, it belonged to the bishopric of Hamar but from 1539 this was placed under the jurisdiction of the bishopric of Oslo. The tabernacle was produced in Antwerp around 1530 and was donated to the church as a votive gift by the parish priest in Ringsaker and prominent canon in Hamar of noble family, Arnstein Jonsson (Skanke). ${ }^{93}$ The doors of the tabernacle are dominated by scenes of martyrdom and the motifs have been interpreted as an expression of fear of the Turks in the light of their advances in the early sixteenth century. ${ }^{94}$ On the outside of the northern door the martyrdom of Saint Sebastian is depicted, the saint pierced by arrows shot by a Turk (Fig. 11.2). In the branches of the tree to which Saint Sebastian is tied, is painted a red coat of arms with a golden Jerusalem Cross, which was the mark of the Kingdom of Jerusalem and associated with Godfrey of Bouillon - and of course the symbol of the knights of the Holy Sepulchre. ${ }^{95}$ This coat of arms is not otherwise known from Norway, but it was of course allowed for knights of the Holy Sepulchre to carry it. ${ }^{96}$ It naturally underlines the crusade context of the entire motif. The tabernacle is a fascinating evidence of the use of crusade motifs to adorn a Norwegian church just before the Reformation.

Arnstein Jonsson, who commissioned the Ringsaker tabernacle, probably died in 1547. An undated note in the archives of the diocese of Hamar states that he was sent on a three-year journey abroad to gain proper knowledge of the Lutheran

92 Flemming Lundgreen-Nielsen and Erik Petersen, eds., C. C. Lyschander's Digtning, 2 vols. (København: Reitzel, 1989), 1:86. See also ibid., 1:24-25.

93 Bente Lavold, "Kultus og status. Kirkeinventar som kilde til kulturelle, sosiale og økonomiske forhold på 1500-tallet," in Alt mellom himmel og jord, ed. Hans Hosar, Skrifter fra Norsk lokalhistorisk institutt 39 (Oslo: Norsk lokalhistorisk institutt, 2003). I am indebted to Bente Lavold for sending a copy of her article to me and drawing my attention to this piece of evidence.

94 Nils A. Ytreberg, "Ringsakers kirkes alterskap i kulturhistorisk lys," Kunst og kultur 61 (1978).

95 Mennenius, "Deliciæ equestrium ordinum," 39-42, 46.

96 Lavold, "Kultus og status” 103, 10-11; Ytreberg, "Ringsakers kirkes alterskap i kulturhistorisk lys." Was Arnstein a knight of the Holy Sepulchre? 
faith. ${ }^{97} \mathrm{He}$ would have found nothing to counter the purpose and message of the motifs. The themes of martyrdom in the light of the Turkish advances would of course fit perfectly into Luther's writings on the war against the Turks and would be as relevant after the Reformation as before. It was therefore in no way strange that Anders Sørensen Vedel should encourage a young Danish nobleman to fight against the Turks to become a martyr, or that he should take the first crusaders as an example. Among those was a very good example that Vedel especially told Erik to follow: the story of the Danish Prince Svend.

\section{Prince Svend}

According to the German chronicler Albert of Aachen, who wrote his chronicle of the First Crusade at the beginning of the twelfth century on the basis of testimonies of returned crusaders, the Danish Prince Svend died in an ambush together with his Burgundian fiancée Florina and 1500 men in Asia Minor on his way to Jerusalem during the First Crusade. ${ }^{98}$ The story was made famous by Tasso's cru-

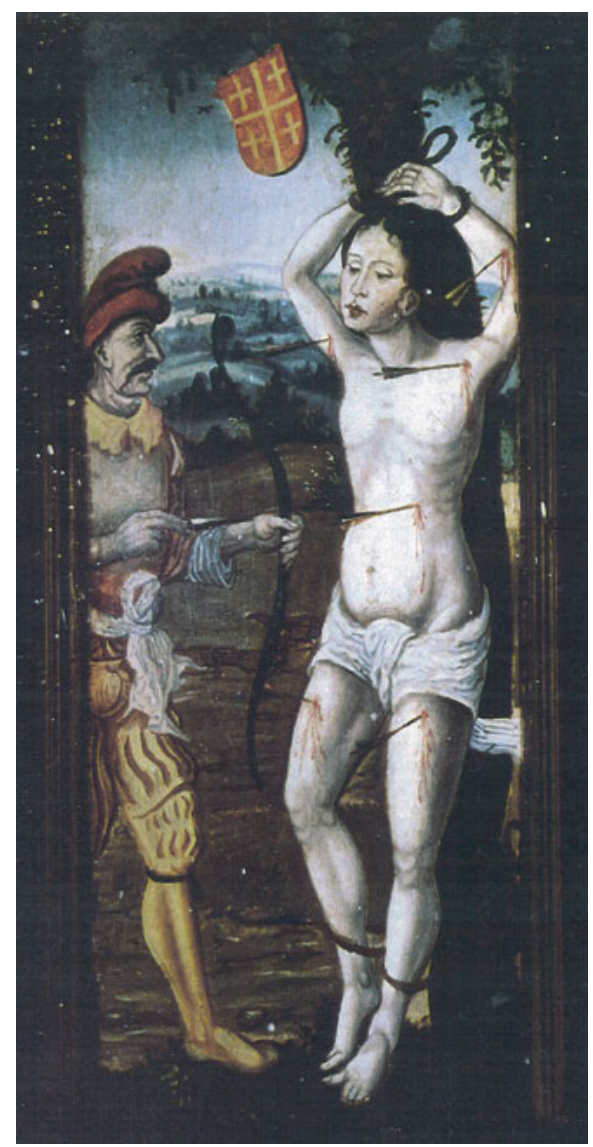

Fig. 11.2: Detail from the Ringsaker tabernacle, produced in Antwerp in the 1530s, depicting the martyrdom of Saint Sebastian. A shield with a Jerusalem-cross is placed in the tree above his head.

97 Lavold, "Kultus og status" 104.

98 Aquensis Albertus and Susan B. Edgington, Albert of Aachen: Historia Ierosolimitana = History of the Journey to Jerusalem, History of the Journey to Jerusalem (Oxford: Clarendon Press, 2007), 222-25. Albert's chronicle was edited by Jacques Bongars in 1611. Cf. Kurt Villads Jensen, "Denmark and the Second Crusade: The Formation of a Crusader State?," in The Second Crusade: Scope and Consequences, eds. Jonathan Phillips and Martin Hoch (Manchester: Manchester University Press, 2001); Janus Møller Jensen, “Danmark og den hellige krig. En undersøgelse af korstogsbevægelsens indflydelse på danmark, ca. 1070-1169," Historisk Tidsskrift 100, no. 2 (2000), 295-96. 
sading poem. ${ }^{99}$ In forewords to the various editions and translations of the poem it was hoped that this story would "once more inspire to erect the theatre of Mars at the gates of Jerusalem." battle by a Danish knight named Karlo. He passed it on to Godfrey of Bouillon, who in turn gave it to a German knight by the name of Rinaldo, ordering him to revenge the death of Svend. This Rinaldo set out to do and in his hand the sword of Svend became the first Christian sword to enter the walls of Jerusalem when the city fell to the crusaders in 1099. The story gave Denmark a special role in the history of the First Crusade which was fully exploited during the reign of Christian IV.

Before 1642 Christian IV had the scene of the recovery of the sword from the hands of the dead Prince Svend depicted in a great painting (Fig. 11.3). ${ }^{101}$ In 1616 a miniature sword was given to twelve Danish nobles who had distinguished themselves in the battle of Kalmar in southern Sweden in $1613,{ }^{102}$ when Christian IV founded a new knightly order called the Armed Arm. Its symbol was an arm clad in armour holding a sword (Fig. 11.4).

It is very likely that this sword represented the sword of Prince Svend. On a medal struck in 1625, the Armed Arm is shown standing on a bible with a lit candle symbolizing the evangelical light with the words pro religione et libertate engraved around it and on the other side a picture of Christian IV (Fig. 11.5). ${ }^{103}$

The knighting ceremony is described by the priest and writer Niels Heldvad (1564-1634): ${ }^{104}$ the first to be knighted was the chancellor Christian Friis to Borreby (1556-1616). A herald told him, "Christian IV wants to make you a knight for your

99 Torquato Tasso, Edward Fairfax, and Willem van de Passe, Godfrey of Boulogne: Or the Recouerie of Ierusalem. Done into English Heroicall Verse, by Edward Fairefax Gent, And now the second time imprinted, and dedicated to His Highnesse: together with the life of the said Godfrey. (London: Printed by Iohn Bill, printer to the Kings most Excellent Maiesty, 1624), Chan. 8, st. 2-42. See above pp. 216-17.

100 Cf. Tyerman, England and the Crusades, 369.

101 Steffen Heiberg and Council of Europe, Christian IV and Europe: The 19th Art Exhibition of the Council of Europe, Denmark 1988, Christian IV og Europa (Copenhagen: Foundation for Christian IV, 1988), 102-03. In a letter dated the 2 February 1642, the learned Stephanius mentions a recent discussion with Ole Worm concerning the identity of Svend, whom he believes to be a grandson of Svend Estridsen (1056-1076), Ole Worm, Breve fra og til Ole Worm, ed. H. D. Schepelern, 3 vols. (Copenhagen: Munksgaard, 1965-68), 2:317-18 (no. 1001).

102 Cf. also Bircherod, "Breviarium equestre".

103 Reproduced in Johann Heinrich Schlegeln and Niels Slangen, Geschichte Christian des Vierten, Königs in Dännemark: 3: Drittes Buch bom Jahr 1613 bis 1629: Mit einigen Medaillen, vol. 3 (Kopenhagen, 1771), facing p. 396; Jensen, "Christian IV og Korstogene," 10.

104 That the sword is the sword of Prince Svend has also been suggested by H. D. Schepelern in Heiberg and Council of, Christian IV and Europe: The 19th Art Exhibition of the Council of Europe, Denmark 1988, 155-56. Cf. Anemette S. Christensen, "Herremandsliv i Danmark 1500-1660," in Svøbt i mår. Dansk folkevisekultur 1550-1700, eds. Flemming Lundgreen-Nielsen and Hanne Ruus (Copenhagen: Reitzel, 1999-2002), 36. 


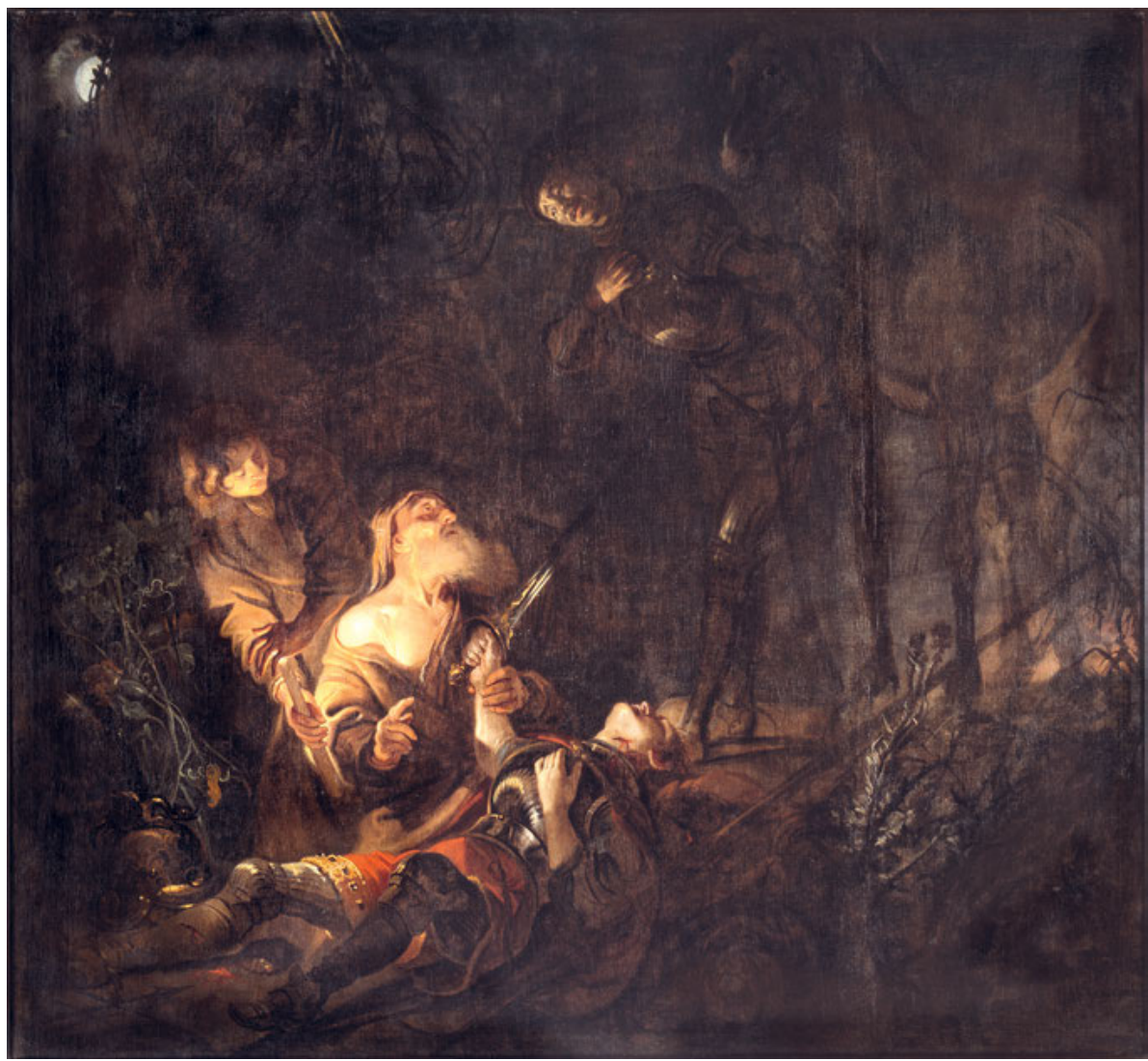

Fig. 11.3: The body of Prince Svend is discovered and his famous sword recovered. Painting by Karel van Mander III (1609-70), commissioned by Christian IV before 1642. National Gallery of Denmark (Statens Museum for Kunst), Copenhagen.

manly and chivalrous deeds, which you performed during the war with Sweden.” Then Christian Friis respectfully stepped forward and kneeled before the king. The king then dubbed him with a "richly endowed" sword, first on the right shoulder, then on the head and the left shoulder, and afterwards handed him the collar of the order. Then the herald proclaimed: "Nun hat S.K.M. Christian Friis würdig geachtet und zum Ritter geschlagen" to the sound of trumpets and drums. ${ }^{105}$ Then the same was repeated for the others in turn.

105 Cf. Schlegeln and Slangen, Geschichte Christian des Vierten, 3, 58-61, where the name of the eleven other knights are also given. The description is found in KB: Thott. $7972^{\circ}$ a copy of the Regum Daniae Icones, fol. 256r. 


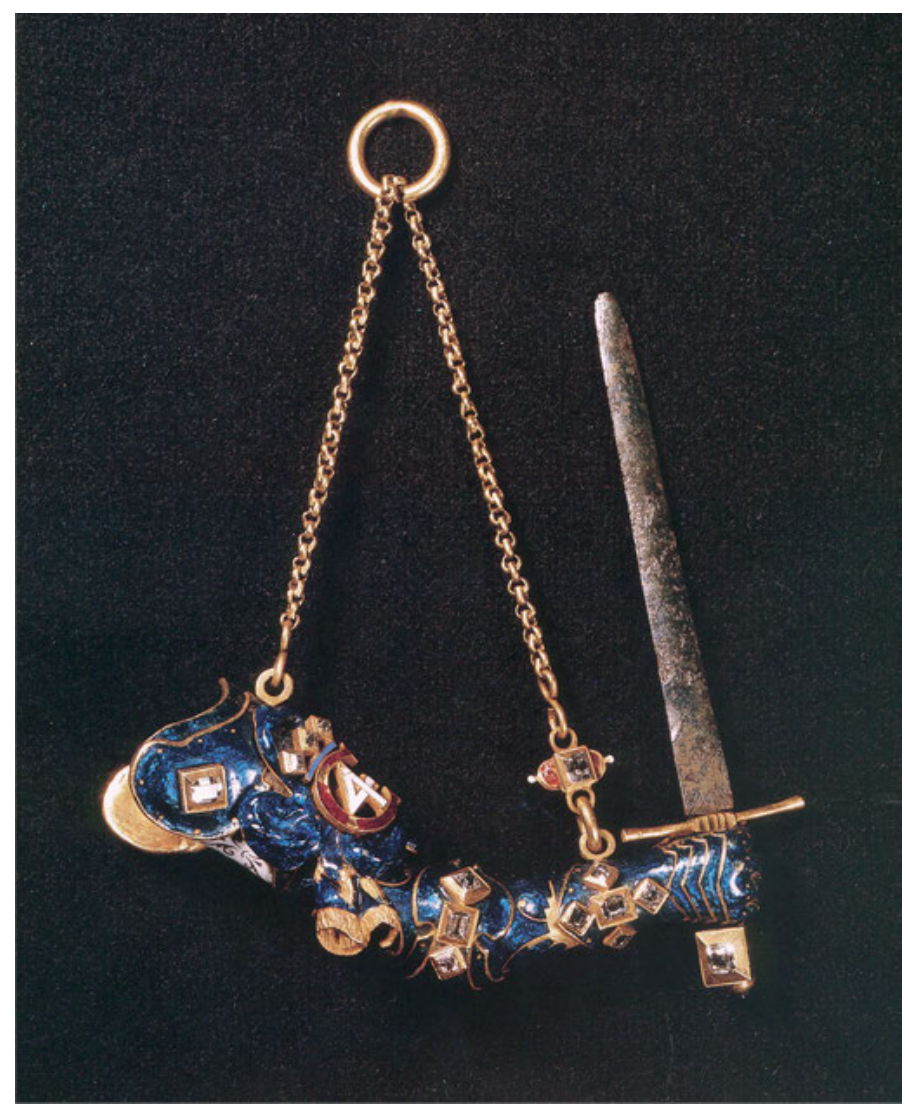

Fig. 11.4: Christian IV's Order of the Armed Arm. Rosenborg Castle, Copenhagen.

Knightly orders of chivalry were an important and central part of knightly and royal ideology in the fifteenth and sixteenth centuries. The Danish Order of the Elephant was created in the middle of the fifteenth century. Its collar was formed of golden elephants with a pendant depicting Saint Mary and the three nails of the crucifixion. ${ }^{106}$ However, in the middle of the sixteenth century the origin and history of the order had become somewhat obscure, when initial steps to have it revived were taken during the reign of Christian III (1536-59). It was, however, left to Christian III's son, Frederik II, to revive the Order around 1570, when it became known as the Order of the Elephant. Its symbolic meaning originated according to its role in the Book of Maccabees, where the war-elephant was interpreted as a symbol

106 Vivian Etting et al., Fra Christian I's Italiensrejse 1474: En latinsk hyldesttale af Filippo Nuvoloni (Copenhagen: Det kongelige Bibliotek and Museum Tusculanum, 1984), 70: "porcum, serpentem, aquilam, corvum.” 


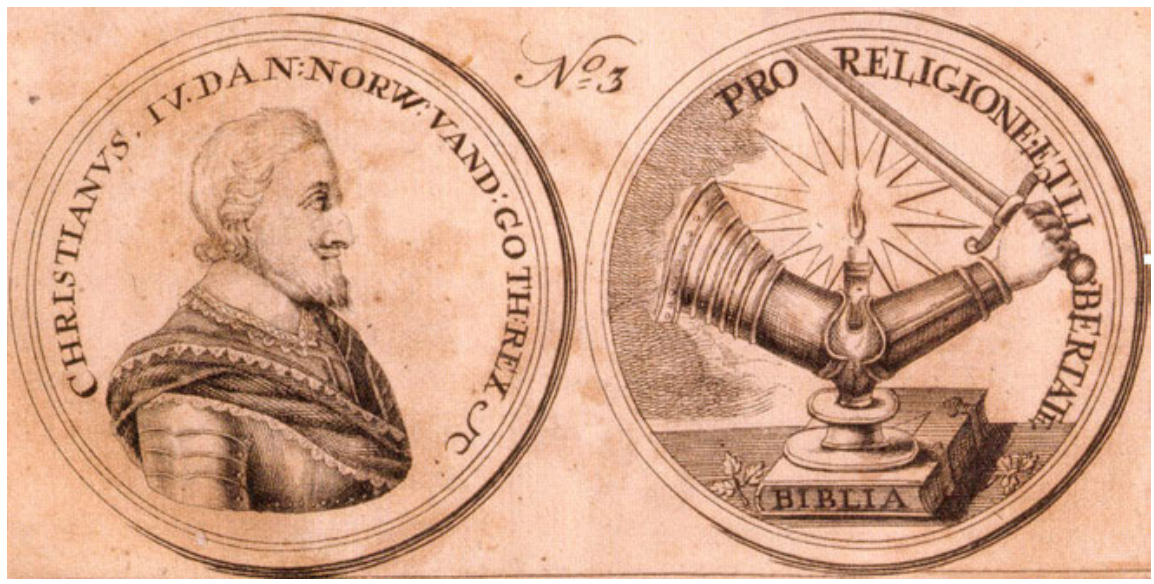

Fig. 11.5: Medal struck by Christian IV showing the Armed Arm standing on a Bible, spreading the Evangelical light. Reproduced from Schlegel 1771: facing p. 396.

of the champion of the faith, who became incensed at the sight of the blood of Christ. In connection with fighting for the faith this fit perfectly into the Protestant princely ideology that became markedly more offensive during the reign of Frederik II.

Frederik Douglas Lockhart has demonstrated how there was a shift in the foreign policy during the reign of Frederik II compared to his father's policy, which had favoured the preservation of the Lutheran faith and well-being of his own subjects above the general course of Protestantism. Frederik II instead immediately went to war in Ditmarsken in 1559 and revived knightly ideals and ideology. He began a more offensive foreign policy, initiated a war with Sweden 1563-70, and involved himself in the early wars of religion against the Catholic powers. ${ }^{107}$ In the spring of 1578, for instance, he recommended several young Danish nobles to serve in William of Orange's (1533-84) armies in the Netherlands against the imperial forces, and even allowed one of his mercenary captains to bring a full cavalry force to the rebel army. From 1583, he joined a Protestant alliance that meant that he should intervene militarily against the Catholics. ${ }^{108}$ It is thus not surprising that Frederik II revived the Order of the Elephant in the 1570 s or that it should have some connection to fighting for the faith. This royal order later swallowed other orders like The Armed Arm. The insignia designed for Christian IV still depicted the Armed Arm, though, and the Armed Arm was awarded again in 1633 and 1634 (Fig. 11.6).

107 Cf. in general Paul Douglas Lockhart, Frederik II and the Protestant Cause: Denmark's Role in the Wars of Religion, 1559-1596, The Northern World 10 (Leiden: Brill, 2004).

108 Lockhart, Frederik II and the Protestant Cause, 202. 


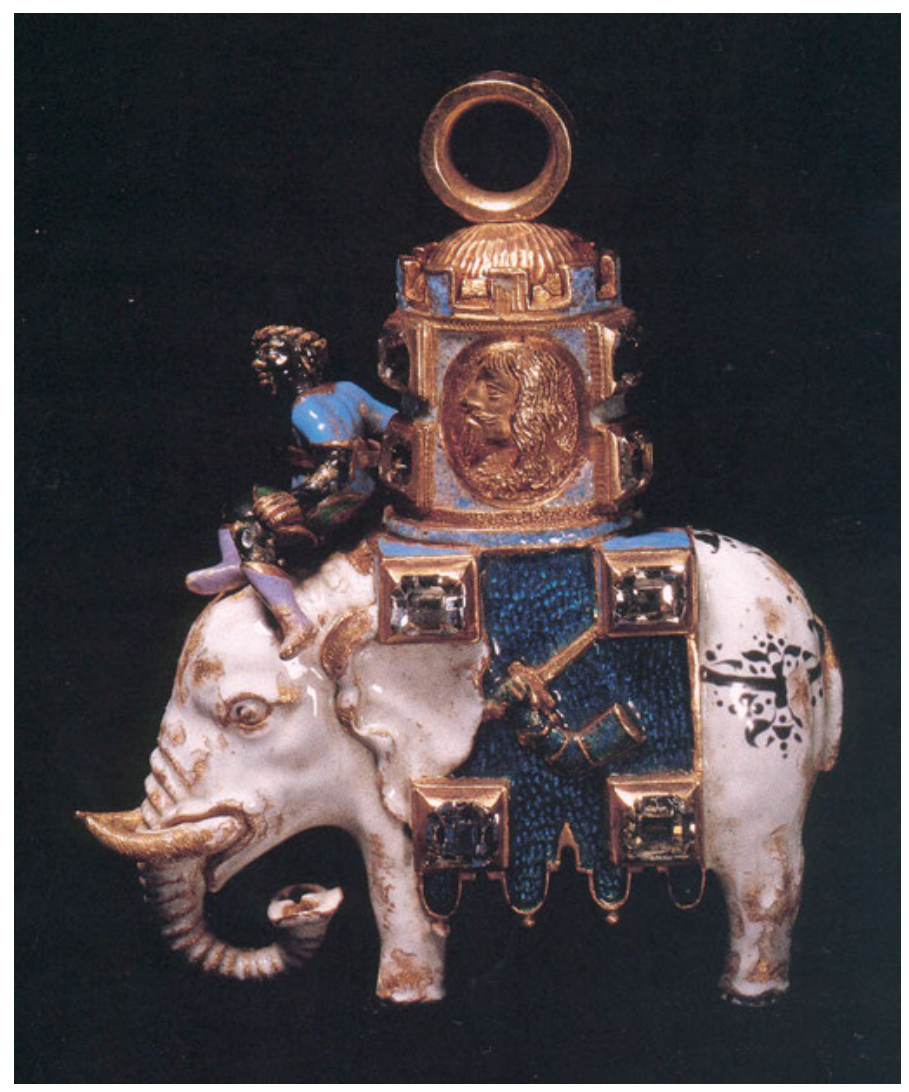

Fig. 11.6: Christian IV's collar of the Order of the Elephant depicting the Armed Arm.

Rosenborg Castle, Copenhagen.

In its fundamental ethos, the Order of the Elephant was connected to the ideology of the crusades. In the seventeenth century, the historians had invented a theory that the order originated with Danish participation in the crusades to the Holy Land. Thus, official Protestant royal ideology took in traditional crusading ideology when creating the history of the royal Order of the Elephant. Perhaps that is why we no longer hear of nobles being knighted at the Holy Sepulchre in the seventeenth century (unless, of course, Henrik Rantzau and others were knighted secretly). Being knighted at the Holy Sepulchre had been overtaken by being knighted by the Danish king in his capacity as representing and fighting for the true faith: the Lutheran-Evangelical confession. However, stories about the first crusaders and their use as examples of heroes circulated widely and probably inspired young Protestant nobles not only to fight for the faith and patria, but also to a continued interest in travelling to Jerusalem. 


\section{The Legend of Dannebrog}

It would go far beyond the scope of the present study to investigate in depth how the militant Protestantism developed during the reigns of Frederik II and Christian IV. It was intertwined with ideas of Denmark as the only realm in the world where the true faith ruled unchallenged, which was celebrated during the first Reformation Jubilee in 1617, and ideas of Denmark as a northern Jerusalem or a safe haven for the church was widespread. ${ }^{109}$ In this process, a national history was created in which the Danish kings and their subjects had always fought for the faith. The Danish national symbols like the national flag and the white heraldic cross in the Danish coat of arms were believed to originate in Danish participation in the crusades.

The legend of the Danish national flag - called Dannebrog - that fell from the sky at Lyndanisse in 1219 was created in the sixteenth century. The two early sixteenth-century historians, Christiern Pedersen and Petrus Olai (1490-1570), knew a source which described this event but told of it in combination with an otherwise unknown crusade in Livonia in 1208. It was Petrus Olai who connected the event to the great Danish crusade to Estonia of 1219. In 1560, the Danish historian Hans Svanning (1503-84) wrote of King Hans's utter defeat in the campaign against Ditmarschen in 1500 that "the banner of the Kingdom with a cross in red and white that according to tradition had fallen from the sky during Valdemar II's (1202-41) war against the Livonians - at that time enemies of Christendom - was captured by the enemies when the commander of the army Hans Ahlefeldt was killed."110 Frederik II recovered it during the second Ditmarschen campaign in $1559 .{ }^{111}$ At his funeral procession in 1588, Dannebrog was placed over his coffin. ${ }^{112}$

A contemporary song relates that during the first assault on the city of Meldorf in Ditmarschen in 1559 the Danes placed the cross-banner at the church tower and remembered the legend of Emperor Constantine's vision of the cross at Ponte Molle in 312, where a huge cross appeared in the sky and a voice declared "In hoc signo vinces". The Dannebrog legend found its final form that we know today in the chronicle of Arild Huitfeldt (1546-1609) of 1599, in which he gave a vivid description of the battle based on Exod 17, making a parallel between the Danish Archbishop Anders Sunesøn praying like Moses with his hands extended towards Heaven for victory,

109 Cf. Jensen, Denmark and the Crusades, 1400-1650, 30.; Paul Douglas Lockhart, "Dansk Propaganda under Kejserkrigen 1625-1629” Jyske Samlinger 2 (1998): 229-42.

110 Hans Svanning, Chronicon sive historia Iohannis regis Dania (Copenhagen, 1560). Svanning does not give the year, which could then be either 1208 or 1219 .

111 Cf. Johan Rantzau, Warhafftige unnd kurtze Verzeychnisz des Krieges (Strassburg: Theodosius Rihel, 1569), fol. L3.; Cimber, "Belli Dithmarsici," 246-47.

112 See the illustration in Hogenberg, "Res gestæ serenissimi potentissimique principis ac domini Frederici II. Etc.," plate 15. 
and Constantine's vision of the cross. ${ }^{113}$ The picture of Moses stretching his hands towards heaven while Joshua fights Amalek was in fact often used in the sixteenth century to defend the church's active role in the war against the Turks. ${ }^{114}$ In his chronicle, Huitfeldt introduced a question of great importance for the present study, when he left it for the reader to decide whether the flag was given to Valdemar by the pope as sign of a crusade - cruciate - or whether it should be taken as a symbol that victory is granted by God alone. ${ }^{115}$ Johannes Isaksen Pontanus (1571-1639), who was commissioned by Christian IV to write a Danish history in Latin for the European public in 1618, followed Huitfeldt's suggestion that it was perhaps granted by the pope for the crusade. ${ }^{116}$

In 1676, however, the learned historian and doctor Thomas Bartholin (1616-80) completely rejected the thesis that it was given to the king as a sign of a crusade. He published a history of the Order of Dannebrog that had just been founded by King Christian V (1670-99) in 1671. He agreed that the flag fell from the sky during the 1219 crusade, and he believed that the Order of Dannebrog had originally been founded on that occasion. ${ }^{117}$ According to Bartholin, Valdemar II had founded the order in commemoration of this great event and to celebrate the two origins of his victory: God and the courage of his soldiers. But Bartholin cannot agree with Huitfeldt and Pontanus that this banner was granted by the pope "when all the reliable Danish annals simply do not mention that this expedition was a crusade [Cruciata] with a single word." 118 According to Bartholin there could be no doubt that the banner fell from the sky as a true miracle. There were plenty of examples

113 Arild Huitfeldt, Danmarks Riges Krønike, 10 vols. (Copenhagen: Rosenkilde og Bagger, 1976-78), 6:106-07. On the use of the figure of Moses, see also Chapter 8 (Martin Berntson), 147-67.

114 Michael J. Heath, Crusading Commonplaces: La Noue, Lucinge and Rhetoric against the Turks, Travaux d'humanisme et Renaissance 209 (Geneva: Librarie Droz, 1986), 17-18.

115 Huitfeldt, Danmarks Riges Krønike, 6:107.

116 Johannes Isaac Pontanus, Rerum Danicarum Historia, Libris X (Amsterdam: Johan Jansson, 1631), 306-07. Cf. for Pontanus and his work Karen Skovgaard-Petersen, Historiography at the Court of Christian IV (1588-1648): Studies in the Latin Histories of Denmark by Johannes Pontanus and Johannes Meursius (Copenhagen: Museum Tusculanum Press, University of Copenhagen, 2002).

117 Thomas Bartholin, Equestris Ordinis Danebrogici (Copenhagen: Georg Gödian, 1676). It was translated into Danish by Gustav Ludvig Baden in 1814: Om Danebrogordenens Oprindelse (Odense: Chr. Iversen, 1814). The translation is equipped with a historical commentary, which Baden respectfully placed in endnotes "in order not to offend the strong believer" with his "heretical remarks immediately below the text of Bartholin."

118 The Danish annals (cf. the editions in M. Cl Gertz et al., Danmarks middelalderlige annaler (Copenhagen: Selskabet, 1980)). of the twelfth and thirteenth centuries use the term "expeditio", which of course was the most common term for crusade at the time. 


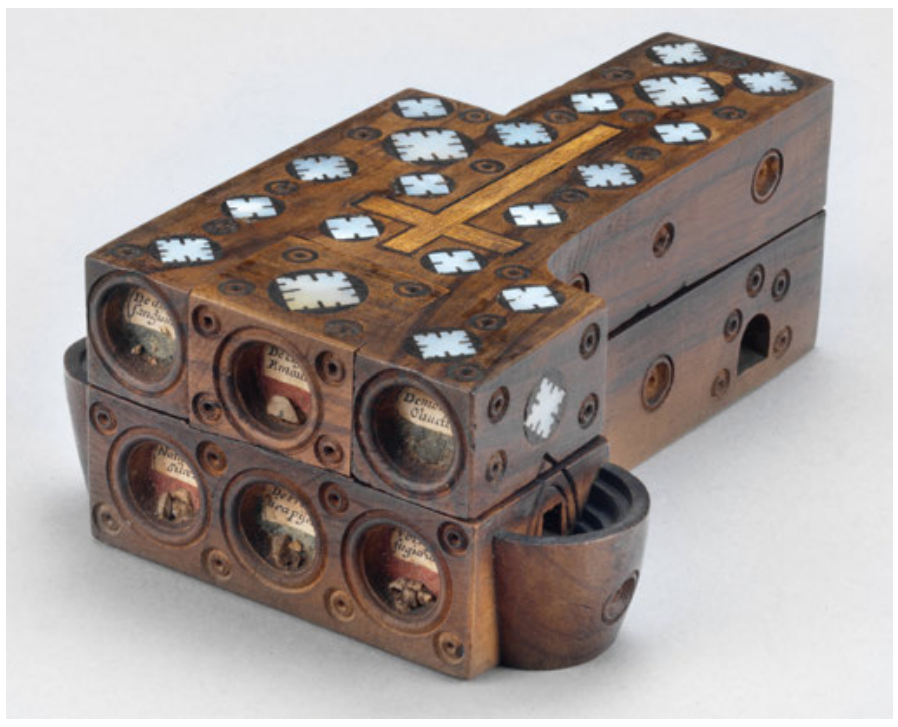

Fig. 11.7: Model of the Holy Sepulchre, brought from The Holy Land to Denmark in 1674. National Museum (Nationalmuseet), Copenhagen.

in history of how God had intervened and performed miracles to convert the heathens. ${ }^{119}$ The banner was given to Valdemar by God, because Valdemar wanted to convert the heathens and to expand Christendom. ${ }^{120}$

During the reign of Christian IV, however, it was Huitfeldt's version of the legend that was authoritative. It was taken over by royal ideology and used in its propaganda. In the early 1590s, Christian IV minted gold coins in imitation of the Portuguese gold coins called portugues or portugaløser in Danish, which combined heavenly visions of crosses - symbolized by the Christ-cross - and the Portuguese crusades. In 1603, a new coin was struck in Denmark, which depicted the Christ-cross surrounded by Christian IV's motto "regna firmat pietas" and "in hoc signe vinces" engraved around it. ${ }^{121}$ As the Danish heraldic specialist, Niels Bartholdy writes: "In this way this type of cross was also in Denmark connected to the ideology of the christianitas militans. The

119 Bartholin, Equestris Ordinis Danebrogici, 6-7. Bartholin may have used the work De Cruce Christi of the Jesuit Jacob Gretzer, who wrote a chapter on all recorded cross-visions of which Bartholin mentions several, Jacob Gretzer, De Cruce Christi (Ingolstadt: David Sartorius, 1600), 1: 527-54. At least the work was used by Lars Norrman in Uppsala to argue against the legitimacy of the crusades to the Holy Land in 1687, Lars Norrman, Dissertatio historico-politica de expeditionibus cruciatis (Uppsala: J. G. Eberdt, 1687).

120 Bartholin, Equestris Ordinis Danebrogici, 12.

121 Niels G. Bartholdy, "Broderskab - selskab - ridderorden. Ordenens ældste historie,” in Fra korsridder til ridderkors. Elefantordenens og dannebrogordenens historie, ed. Mogens Bencard and Tage Kaarsted (Odense: Odense Universitetsforlag, 1993), 43-45. 


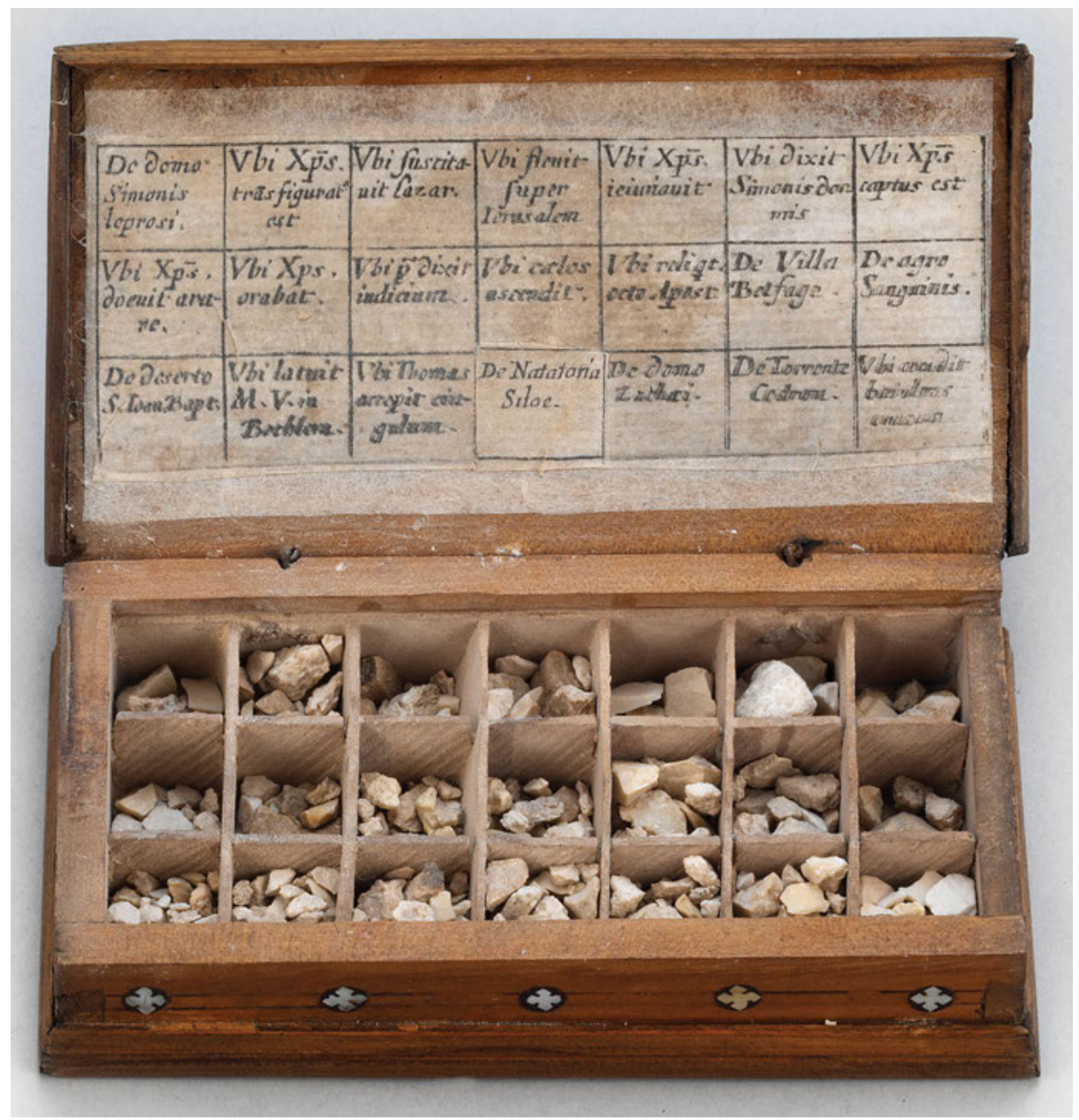

Fig. 11.8: Casket with relics from the Holy Land, brought to Denmark in 1674. National Museum (Nationalmuseet), Copenhagen.

addition of the famous sentence no doubt was due to Huitfeldt's chronicle that had been published just a few years prior." 122

Huitfeldt explicitly linked the cross in the Danish coat of arms to the Danish involvement in the crusades in the Baltic: "For this reason - that King Valdemar planted the Christian faith in Livonia - the white cross is carried in the Danish

122 Bartholdy, “Broderskab - selskab - ridderorden,” 44. 
arms." ${ }^{23}$ He even acknowledged that this was granted to the Danish kings by the pope. Under the year 1249, he wrote of King Erik Plovpenning (1241-50): “previous popes had given his father cruciatam, that is the Christian cross to carry in his coat of arms."124 Crusading ideals thus became an important part of shaping Danish royal and national ideology. It should come as no surprise that the nobles who read stories about the crusaders' struggle in Jerusalem, the heroes of the first crusade from Godfrey of Bouillon to Prince Svend, and the war against the enemies of the faith by the Danish proto-crusader Ogier the Dane, became inspired to undertake the journey to Jerusalem. Pilgrimages in the Catholic sense might have waned and finally disappeared. However, the medieval crusade as part of Danish national history and identity created in the sixteenth century, continued to appeal to Lutheran nobles and in this respect, the continuity from the medieval past is much more obvious.

\section{Conclusion}

With the Reformation in Denmark the medieval pilgrimages to Jerusalem that had been common and an important part of late medieval religious life came to a contemporary halt. They were revived in the second half of the sixteenth century where they became part of the educational journeys of the Danish nobility. The travel accounts, however, reflect a strong interest in the many holy and biblical sites and places. Even if some of the authors of the accounts only record what is said at the holy sites, they still faithfully report all they see and are told. Beside the interest in the scenes for the passion of Christ, a particular interest in crusading history and being knighted at the Holy Sepulchre are singled out. This coincides with a renewed interest in crusading history that became part of Danish national history and identity in which both the kings and nobility had a long tradition for fighting for the true faith. This is reflected in both official and authoritative historical writing and literature. The nobles read about the wars and battles of Ogier the Dane as a kind of proto-crusader and champion of the faith. They read about the first crusades and the Danish crusading heroes like Prince Svend and fought under national banners and symbols that explicitly were believed to have originated in the crusading past of Denmark. There was a deliberate identification of being created a knight of the Holy Sepulchre and being a golden knight in Denmark. This siutation changes at the turn of the seventeenth century when the nobles apparently no longer were knighted at the Holy Sepulchre but

123 Huitfeldt, Danmarks Riges Krønike, 6:106-07: "For denne Aarsage Skyld, at Konning Woldemar [II] udi Liffland haffuer indplantet den Christelige Tro, føris udi Danmarckis Vaaben det huide Kaars.”

124 Huitfeldt, Danmarks Riges Krønike, 6:191: “fordumme Paffuer haffuer giffuet hans Herrefader Cruciatam, det er det Christne Kaars udi Vaben, Menendis sig oc der met at vinde en Fortieniste hos Gud.” 
instead were created knights of the new orders of chivalry in Denmark that were also believed to originate in the crusading past of Denmark. Fighting for the faith and the struggle to liberate Jerusalem and the Holy Land thus need to be taken into consideration when investigating the motives behind the Jerusalem journeys in the sixteenth and seventeenth century. In this respect, they are linked to the medieval crusading past that became part of the national Protestant crusading ethos of the sixteenth and seventeenth century. Fighting for the faith became identified with fighting for Lutheran-Evangelical confession and the patria. Jerusalem thus slowly became less important as a destination in itself. Instead, it became one of several important biblical sites that travelers had to visit including Egypt and Ethiopia in particular. During the seventeenth century, this antiquarian interest in biblical events became increasingly predominant, as will be further explored in volume 3 of this publication. Rather than forming part of the education of the nobility, scholars began to visit these places for the study of languages and other scholarly interests, which might be seen as forerunners for the high-profile scientific expeditions of the eighteenth century. The literary interest in crusading history and stories in the sixteenth and seventeenth centuries undoubtedly kept the idea of going to Jerusalem and being knighted at the Holy Sepulchre alive as part of or an extension of a medieval tradition. Only slowly did this turn into something else when Jerusalem, as argued for other European countries, became a symbol for the new national monarchy, and fighting for faith became identified with the wars of the patria. ${ }^{125}$ Jerusalem like the other crusading symbols thus became overtaken and nationalized by the ever stronger national monarchy in Denmark.

125 Cf. Housley, “Holy Land or Holy Lands?”; “Pro Deo Et Patria Mori”. 


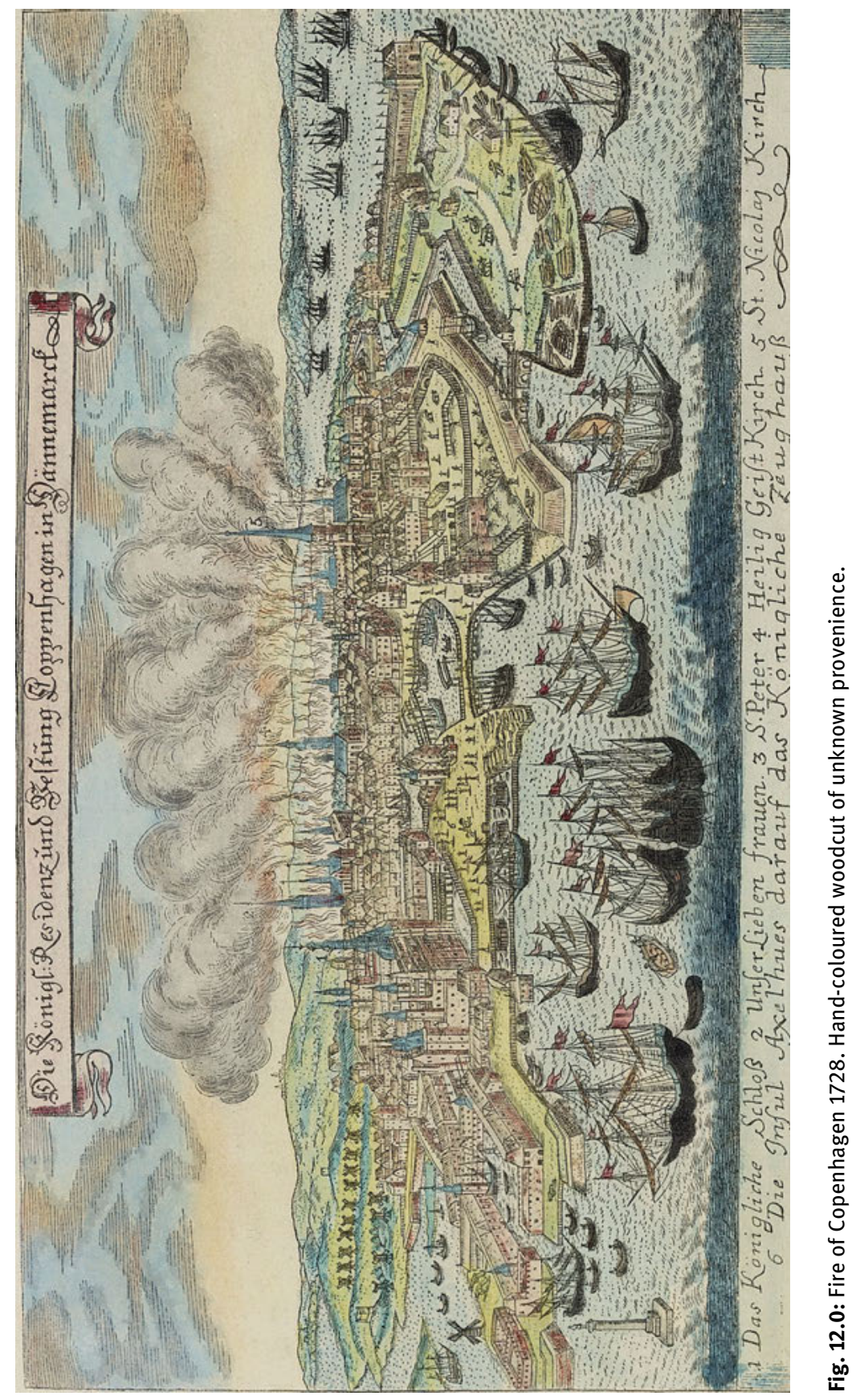

